This item was submitted to Loughborough's Research Repository by the author.

Items in Figshare are protected by copyright, with all rights reserved, unless otherwise indicated.

Monitoring of a landfill side slope lining system: instrument selection, installation and performance

PLEASE CITE THE PUBLISHED VERSION

http://dx.doi.org/10.1016/j.geotexmem.2012.06.003

PUBLISHER

(C) Elsevier Ltd.

VERSION

AM (Accepted Manuscript)

LICENCE

CC BY-NC-ND 4.0

REPOSITORY RECORD

Zamara, Katarzyna A., Neil Dixon, D. Russell V. Jones, and Gary John Fowmes. 2019. "Monitoring of a Landfill Side Slope Lining System: Instrument Selection, Installation and Performance". figshare. https://hdl.handle.net/2134/12743. 
This item was submitted to Loughborough's Institutional Repository (https://dspace.lboro.ac.uk/) by the author and is made available under the following Creative Commons Licence conditions.

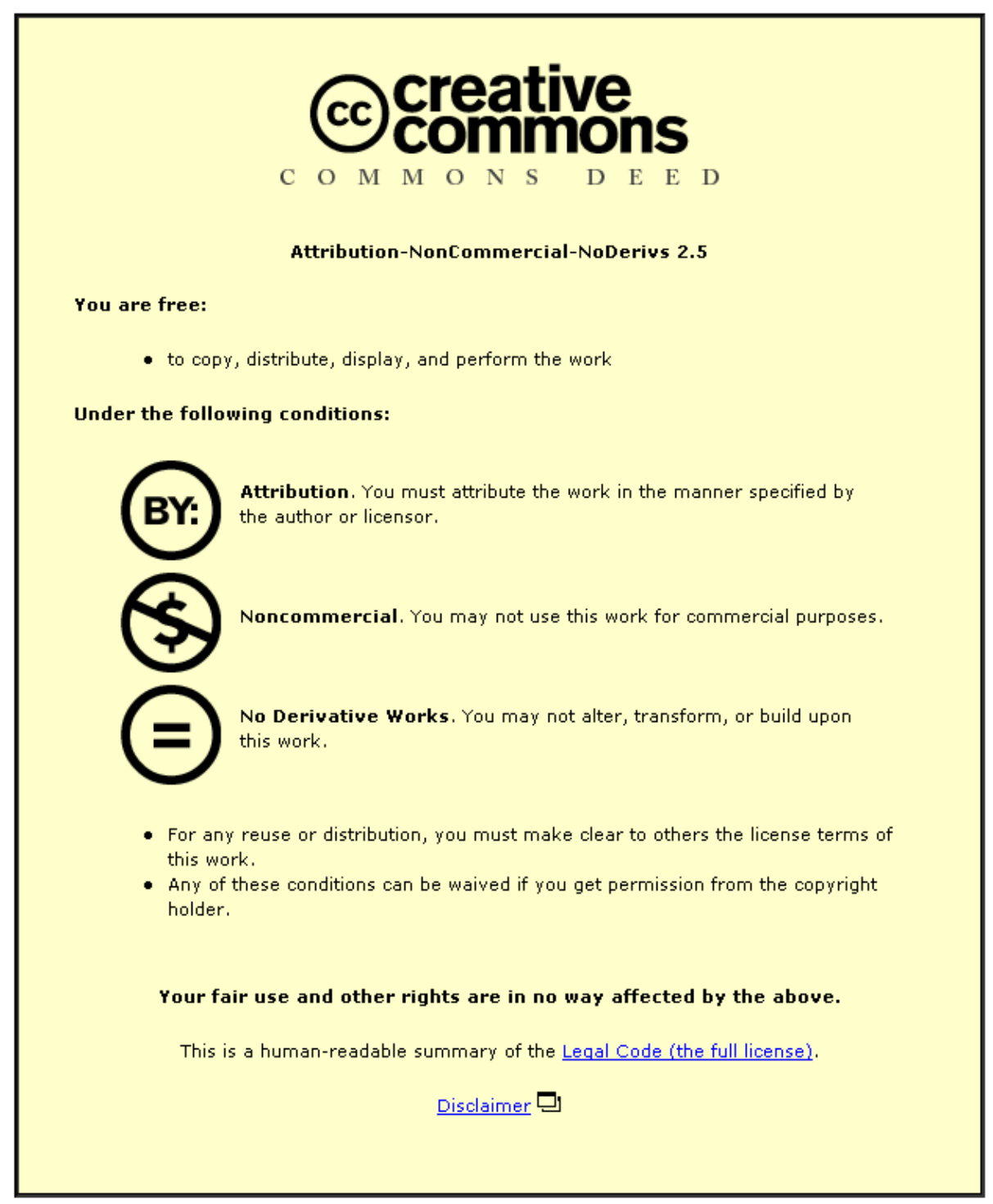

For the full text of this licence, please go to: http://creativecommons.org/licenses/by-nc-nd/2.5/ 


\title{
Monitoring of a landfill side slope lining system: Instrument selection, installation and performance.
}

\author{
Katarzyna A. Zamara \\ CICE, School of Civil and Building Engineering, Loughborough University LE11 3TU \& Golder Associates \\ (UK) Ltd Nottingham, NG12 5BL, UK. K.A.Zamara@lboro.ac.uk
}

Neil Dixon

School of Civil and Building Engineering, Loughborough University, LE11 3TU, UK. N.Dixon@lboro.ac.uk

\author{
D. Russell V. Jones \\ Golder Associates (UK) Ltd Nottingham, NG12 5BL, UK. R.Jones@lboro.ac.uk

\section{Gary Fowmes} \\ Waste Recycling Group, Nuneaton, CV10 0HU, UK, gary.fowmes@wrg.co.uk
}

\begin{abstract}
Municipal solid waste landfill barrier systems often comprise a combination of geosynthetics and mineral layers. Throughout the last twenty years there has been extensive research on the interactions between the materials and on performance of the geosynthetics including aspects of durability. This research has resulted in significant advances in the design and specification of landfill lining systems. However, to date there has been limited research carried out on in situ landfill lining system behaviour. Measured behaviour from field scale trials and of in service operation can provide valuable information on landfill lining system performance and allow a better understanding of composite material behaviour. Although many numerical modelling programs are applied to evaluate lining system stability and integrity, data to validate these models is currently limited. This paper highlights the data required to validate numerical models and instrumentation techniques that may be used to acquire this information. The paper focuses on geotechnical instrumentation deployed on the side slope lining system at the Milegate Extension Landfill, UK. The instrumented lining system comprises $1.0 \mathrm{~m}$ of compacted clay, a $2 \mathrm{~mm}$ double textured high density
\end{abstract}


polyethylene geomembrane, a nonwoven geotextile and a sand cover soil layer. Instrument selection and problems associated with acquiring consistent, reliable and valuable data in a field environment are discussed, as are the challenges and problems that occur when preparing a full scale experiment. Sources of uncertainties within readings are highlighted. Additionally, initial results collected during sand veneer layer placement on the slope are presented. These demonstrate acceptable instrument performance over a 2 year period. Measured behaviour highlights the significance of geomembrane strains driven by temperature changes, generation of post peak strengths at interfaces during fill placement on the side slope due to relative displacement at interfaces between components, and mechanisms of stress redistribution in the geomembrane that result in time dependent changes in strain under constant load and temperature conditions. 


\section{$1 \quad$ Introduction}

Modern landfill engineering in the UK involves detailed analysis of construction and environmental matters in order to meet requirements of the Environmental Agency, European Union regulations and UK legislation. This is to minimise impact on human health and ensure environmental safety. According to the Council Directive 1999/31/EC (1999) official required measures are associated with landfill emissions: leachate volume and composition, surface water composition, gas emission and atmospheric pressures, these are related to waste classification. While advanced systems of design and construction are mandatory according to Landfill (England and Wales) Regulations (Environment Agency 2002), there is no formal requirement to monitor directly the mechanical performance of the lining system. Monitoring parameters focus on the environmental impact of the liner's performance (eg. groundwater contamination) and reported data in the case of exceeded values may relate to an already damaged liner. Even when monitoring is required as a condition of the license for a particular landfill, data is often not published. Information about lining system performance can be derived from back analysis of large scale landfill failures (Koerner and Soong 2000, Dixon and Jones 2003, Muhsiung 2005) but these cannot provide insight into in-service performance of nominally stable facilities. Current practice in landfill design involves applying numerical modelling software and employing complex methods for predicting landfill lining system behaviour to evaluate displacements, strains, and tensile stresses resulting from waste body lining system interaction (Dixon and Jones 2003). However, there is still little attention given to in-service performance of landfill lining systems and interaction of the materials within a barrier system. Although in-service failure can lead to environmental damage, commonly used design approaches have not been verified through monitoring of liner behaviour during construction, filling and after closure. 
To meet requirements for an environmentally safe landfill it is important to maintain the lining system stability (ultimate limit state) and integrity (serviceability limit state) throughout the landfill lifetime. While stability of the landfill involves large scale movements (e.g. slope failure), integrity is related to overstressing of liner elements with consequent loss of original functions, according to which the liner was designed (e.g. low permeability barrier, protection layer). The key areas for a landfill design engineer are: side slope (steep/shallow) stability/integrity, basal lining system stability/integrity, subgrade behaviour, ground water behaviour, appropriate material selection for the barrier components and waste parameters. It is of high importance to build environmentally safe landfill constructions and to assess adequately the performance of landfill lining systems and in particular, to predict stresses and strains in lining elements resulting from waste placement and settlement. To the Authors' knowledge only a limited number of full scale geotechnical landfill monitoring research projects have been conducted to investigate landfill liner behaviour (Gourc et al. 1997, Bouthot et al. 2003, Nakamura et al. 2006) but a limited number of long term monitoring experiments with back analysis have been reported (Najser et al. 2010, Villard et al. 1999). Although there is an increasing number of laboratory projects investigating lining system behaviour (e.g. Gourc et al. 2010, Koerner et al. 1997) and attempts to develop software calibration have been undertaken (Vilard et al. 1999, Fowmes et al. 2008), there is still an urgent need for information on in-service physical performance of barriers. Additionally, much attention has been given to landfill temperature monitoring and assessment of landfill lining system durability depending on liner temperature (i.e. Rowe and Sangham 2002, Rowe et al. 2008, Rowe and Hoor 2009) and also studies of waste body parameters and mechanical properties have been reported (Fassett et al. 1994, Gotteland et al. 2002, Dixon and Jones 2005, Stoltz et al. 2010). Nevertheless, limited 
information exists about geosynthetics liner performance throughout cell operation and after closure.

The aim of an ongoing study conducted by the Authors is to validate design approaches. This paper reports an investigation of the mechanical performance of a multilayered landfill lining system (Figure 1) at various stages of landfill development (i.e. barrier response to applied pressures in relation to waste placement during subsequent stages of cell filling, waste compaction and liner performance after cell closure due to waste settlement). This paper describes the challenges associated with design of a landfill lining monitoring system. It reports the research conducted at Milegate Extension Landfill in East Yorkshire, UK (Figure 2), where a section of landfill slope has been monitored using geotechnical instrumentation to measure stresses imposed on the liner, displacements within and between the lining elements, strains within the liner elements, and also temperature of the clay surface and geosynthetics. This provides an opportunity to obtain valuable information to aid the design of future landfill lining systems and to assess performance of existing systems. Problems associated with waste barrier interactions, interface properties and mechanisms involved in certain material/interface behaviour are also investigated. The project started in June 2009. Instrumentation consists of pressure cells (PC), extensometers, fibre optics (FO) and Demec strain gauges. In addition, site slope surveys were conducted using laser scanning. To date, response of the lining system to placement of three soil veneer layers and $9 \mathrm{~m}$ thickness of waste body has been recorded. 


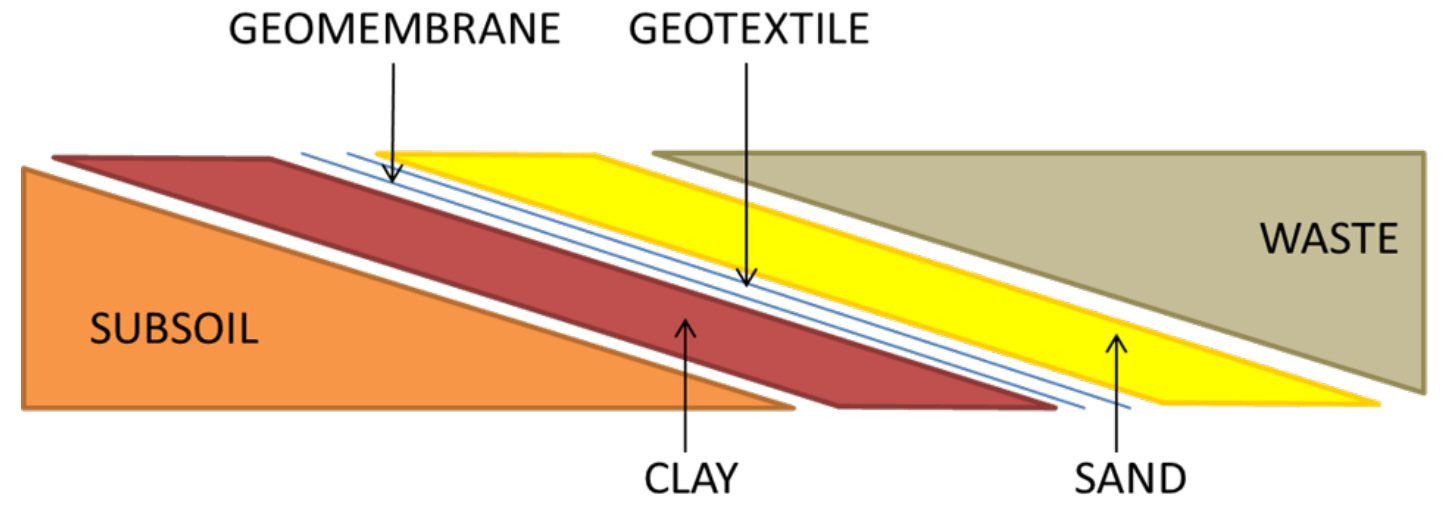

Figure 1. Schematic view - Milegate landfill multilayered side slope lining system.

\subsection{Context of the research}

Construction of landfill barriers typically involves placement of geosynthetic materials over a mineral layer, which is often compacted clay. Further, landfill construction often comprises a mineral drainage layer and subsequent placement of waste layers. In the last 15 years there has been significant improvement in understanding of landfill lining systems. Numerical modelling codes have been developed with specific functions for analysing landfill site geotechnical problems (Fowmes et al. 2008, Villard et al. 1999) including staged placement of municipal solid waste, mobilized shear strength of the geosynthetic lining system interfaces (strain softening and progressive failure), tensile stresses in geosynthetics elements and representation of waste behaviour (Zhang 2007, Machado et al. 2002). Construction stages result in deformation of components and hence shear stresses developed between and within materials and consequently formation of tensile stresses in the geosynthetic elements. The importance of several factors has been established and these should be considered when designing landfill lining system. They include consideration of progressive failure through strain softening of interfaces between geosynthetics and geosynthetics/soil materials, staged placement of the waste body, consideration of tensile stresses in geosynthetics, and assessment of waste properties such as unit weight, stiffness and strength, and their change due to ageing, deformation and settlement. An important challenge is the selection of peak or 
residual interface shear strength parameters for use in limit equilibrium stability analyses of multi-layered lining systems. The importance of accurate prediction/design of engineering aspects of landfill behaviour is self evident.

Previous studies undertaken to investigate landfill liner behaviour have been based on back analysis of monitored slopes (Villard et al. 1999), laboratory results (Fowmes et al. 2008), landfills failures (e.g. extensive numerical and laboratory analysis of Kettlemen Hill failure - Seed et al. 1990, Byrne et al.1992, Mitchell et al. 1990, Chang et al. 1999) and parametric studies partially based on global databases (Kodikara 2000, Sia 2007). However, a validated approach taking into consideration the full complex nature of the landfill lining systems is still unattainable, and research is required to achieve a better understanding of the material behaviour and interaction mechanisms incorporated in models, to remove conservatism in the design process and to assure confidence and optimal construction geometry.

Recently, a number of laboratory investigations have been carried out using centrifuges (i.e. size reduced models with increased model weight, which simulates in situ stress conditions). Thusyanthan et al. (2007) conducted tests to investigate tension within geomembranes (GMB) occurring due to static and dynamic loadings and compared these with results of limit equilibrium methods. Gourc et al. (2010) reported a test carried out on landfill clay capping in a centrifuge in order to investigate deformation within cap barrier and Viswanadham and Rajesh (2009) investigated behaviour of landfill basal clay barrier and the effect of differential settlement.

\section{$2 \quad$ Details of the Field Trial}

Milegate Extension Landfill is located in East Yorkshire, UK, at National Grid Reference TA 131472 (Figure 2). The void used for the landfill cell was formed as a result of sand and gravel extraction. The landfill accepts inert and non-hazardous, building, agricultural, 
commercial and industrial waste. However mostly the waste body comprises of household, campsite wastes and limited construction site waste.

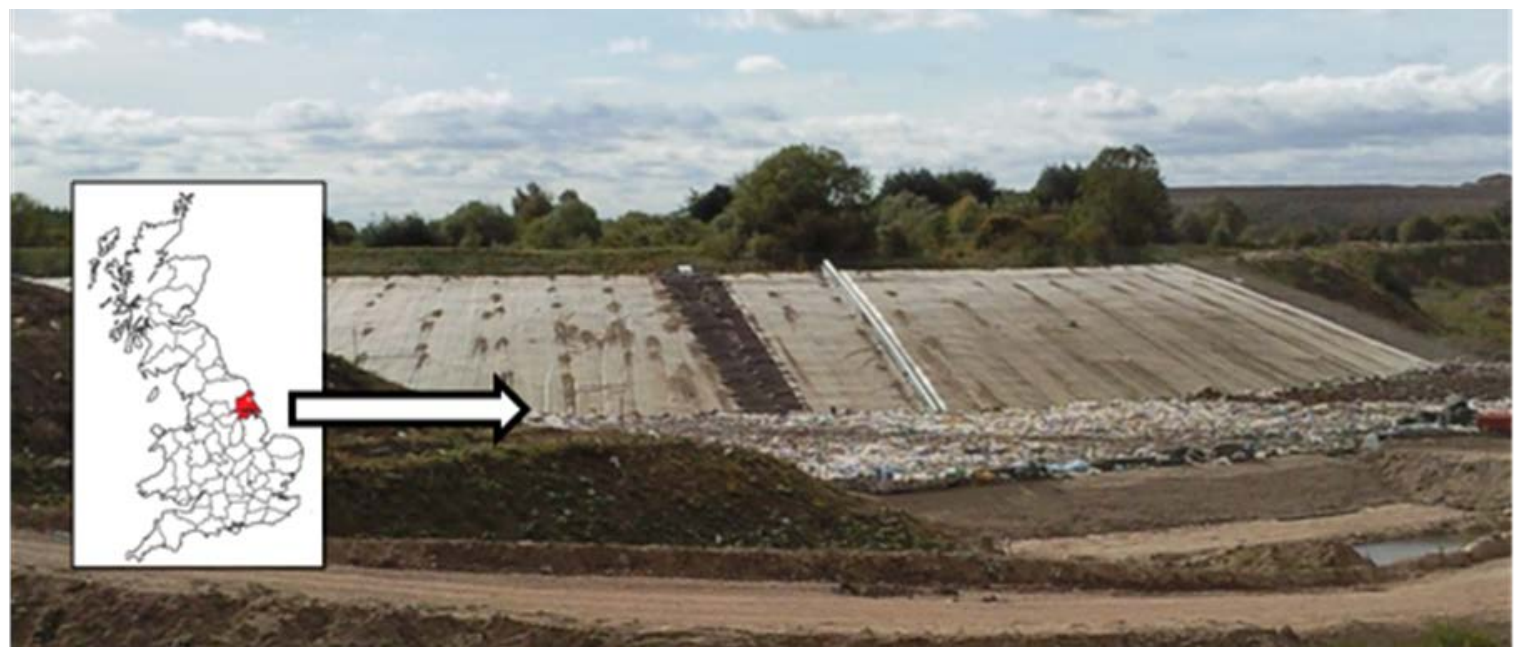

Figure 2. Milegate Extension Landfill, monitored section (black strip in centre of the slope) in cell 3 and site general location.

The monitored slope has a length of $31.2 \mathrm{~m}$ and is $12 \mathrm{~m}$ high with an inclination angle of $1 \mathrm{v}: 2.5 \mathrm{~h}\left(\sim 21.8^{\circ}\right)$. Figure 3 presents the general geometry of the slope. The geosynthetic lining system deployed during the experiment was placed in addition to the existing-clay liner, and therefore is an additional and hence sacrificial layer that does not form part of the approved containment system. The combination of materials within the lining system: clay, GMB, geotextile (GTX) was chosen to represent common practice in the United Kingdom. One panel of the geocomposite drainage material that covers the clay liner over the whole cell was replaced by one 5m wide panel of the high density polyethylene (HDPE) GMB and GTX trial lining system.

The instrumented lining system comprised a 2 mm double textured HDPE GMB 5 m wide, density $0.949 \mathrm{~g} / \mathrm{cm}^{3}$ (GMB TMT from Atarfil S.L.). Information on the tensile stress/strain behaviour of the GMB is available from the manufacturer and will be used as input data for the numerical modelling study. The GMB is overlain by a non-woven needle punched GTX 5m wide panel. This protection layer has a static puncture strength [CBR] of $14 \mathrm{kN}$, thickness of $7.8 \mathrm{~mm}$ and weight of $1400 \mathrm{~g} / \mathrm{m}^{2}$ (HPS14 from GeoFabrics Ltd). The 
manufacturer's data on tensile stress/strain behaviour will also be used as input data for the numerical model. The multi-layered landfill system is schematically presented in the Figure 1. The GMB and GTX were placed along the entire length of the side slope and fixed at the top of the slope in a " $U$ " shaped $600 \mathrm{~mm}$ x $600 \mathrm{~mm}$ anchor trench.

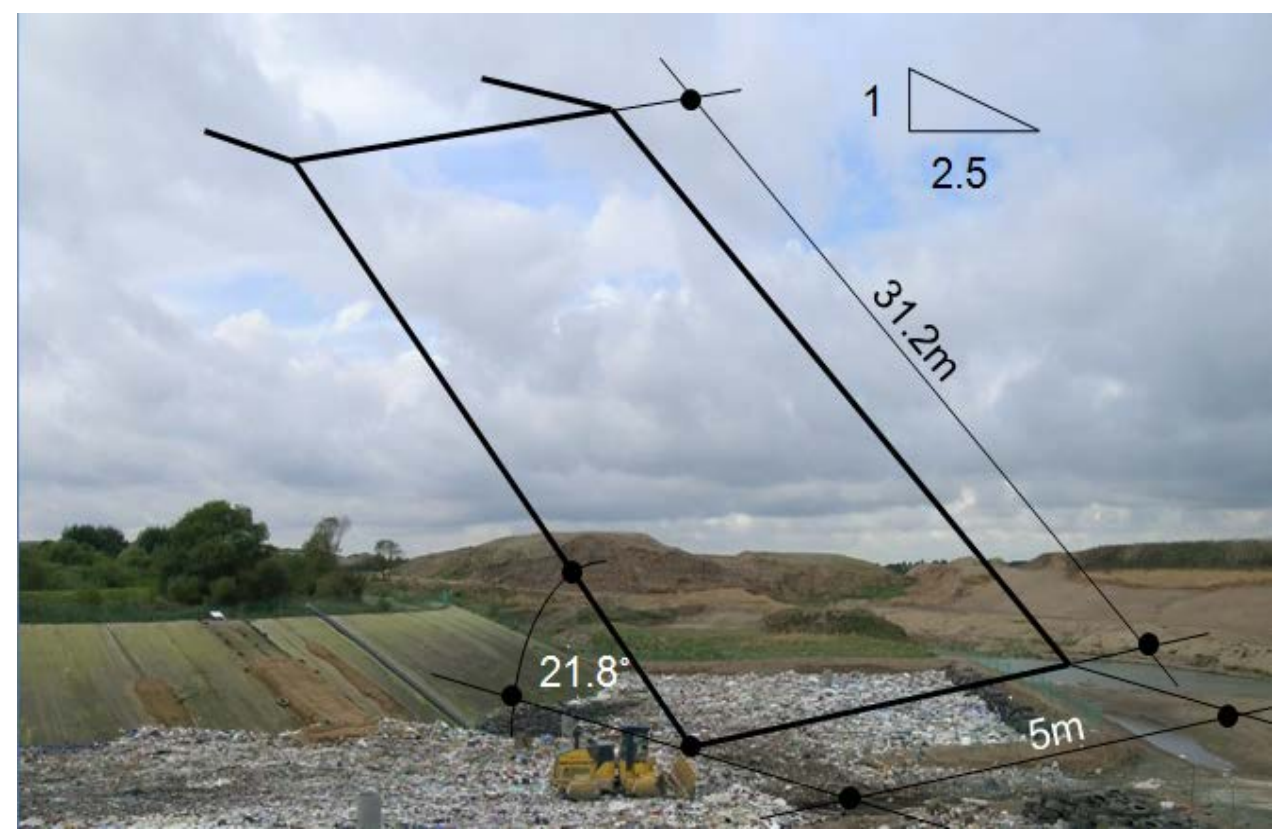

Figure 3. Milegate Extension Landfill - slope geometry.

A nominally $0.5 \mathrm{~m}$ thick sand veneer was placed in stages on the GTX ahead of waste placement. This represents the common practice of providing a mineral drainage layer on side slopes. This would typically be a gravel drainage layer but as this material was not locally available, sand was used as a replacement as it produces loading equivalent to the medium to coarse gravel typically used for mineral drainage layers. Although use of sand does not represent current construction practice it is not significant because the numerical modelling phase of the study will model the constructed configuration, with results compared to the observed site behaviour. Prior to waste filling the sand layer was placed parallel to the slope along $10 \mathrm{~m}$ of slope length. When the waste body reached the top of the first veneer a second $10 \mathrm{~m}$ long sand layer measured parallel to the slope was placed along the slope. When the waste reached the top of the second veneer layer a third and last veneer trial was 
constructed such that the whole length of the slope was covered with a $0.5 \mathrm{~m}$ thick sand layer. Placement of the sand veneers provides opportunity to measure response of the underlying geosynthetic components to the applied load. The sand veneer was placed by a digger arm. It was compacted using the bucket and not traversed by the digger (the arm was sufficient length to place the full length of veneer without tracking on placed sand). This paper presents results from the second veneer trial (Figure 4). History of undertaken and planned works is presented chronologically in Table 1.

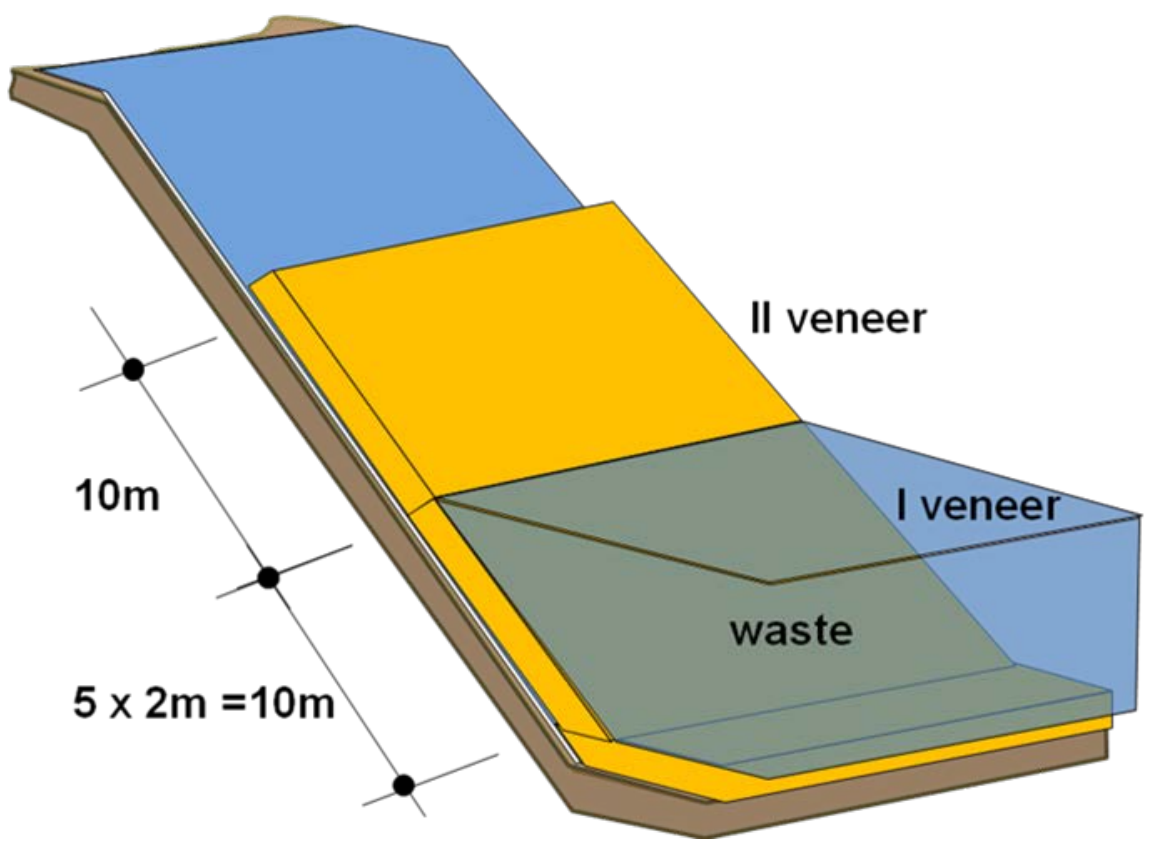

Figure 4. Stages of sand veneer construction and waste filling 


\begin{tabular}{|l|l|}
\hline Description of the event & Date \\
\hline Installation of the instrumentation/materials; & $07 / 2009$ \\
\hline $\begin{array}{l}1^{\text {st }} \text { sand veneer; } \\
10 \text { m of the lower part of the slope under the veneer; }\end{array}$ & $11 / 2009$ \\
\hline 1st scanning; & $11 / 2010$ \\
\hline $\begin{array}{l}\text { 2nd sand veneer; } \\
\text { 20m of the lower part of the slope under the veneer; }\end{array}$ & $11 / 2010$ \\
\hline 2nd scanning; & $11 / 2011$ \\
\hline $\begin{array}{l}\text { 3rd sand veneer; } \\
\text { Demec gauges covered by the veneer; } \\
\text { All the slope covered by the veneer; }\end{array}$ & $11 / 2011$ \\
\hline Planned: whole length of the slope covered with waste; & Summer 2012 \\
\hline
\end{tabular}

Table 1. History of the works undertaken on the monitored slope. 


\section{$3 \quad$ Liner Instrumentation}

Suitable selection of the instruments for a multilayered lining system (clay/GMB/GTX/sand) was of significant importance for the study. Instruments are expected to deliver data for several years. More importantly, as the main aim of the study is numerical model validation, it was important to measure parameters related to design criteria (e.g. displacement, strain, tension, pressure). High confidence in adequate instrument performance was of importance as damaged sensors are difficult to repair once waste has been placed.

The key aspects of instrumentation selection for this project can be listed as follows:

- To minimize instrumentation impact on the barrier in situ performance (i.e. so the instrumentation placement does not modify the measured values);

- To ensure instrument/material durability during interaction with the landfill environment;

- Provide desired accuracy;

- Design instruments for relatively simple and easy instalment in the landfill environment (i.e. maximum laboratory preparations to minimize and accelerate site works);

- Reasonable cost of the instrument;

- Minimise required maintenance works and hence implication for costs; and

- Provide the possibility of comparing results between different methods of measurement.

Instrumentation selected for Milegate Extension Landfill monitoring system, the numbers of sensors/instruments and measured parameters are listed in Table 2. Ongoing analysis of instrumentation readings resulted in purchase of the temperature logger to record GMB temperature in order to aid identification of relationships between measured behaviour of liner components in response to temperature changes. It is important to rigorously assess all 
the collected data in order to identify inconsistency or unexpected behaviour of the instruments. This ensures the recording of valuable, reliable and comprehensive data. Early verification of the results and determination of errors/inconsistency allows for instrument adjustments or replacement.

\begin{tabular}{|l|l|l|}
\hline \multicolumn{1}{|c|}{ Instrument } & \multicolumn{1}{|c|}{$\begin{array}{c}\text { Number of } \\
\text { instruments/ sensors }\end{array}$} & Measured parameter \\
\hline $\begin{array}{l}\text { Vibrating Wire } \\
\text { Pressure Cells }\end{array}$ & 4 & Normal Stress \\
\hline Extensometers & 12 & $\begin{array}{l}\text { Displacement (at 6 points } \\
\text { on the GMB, on the } \\
\text { GTX) }\end{array}$ \\
\hline $\begin{array}{l}\text { Demec strain } \\
\text { gauges }\end{array}$ & 16 steel disks & $\begin{array}{l}\text { GMB strains across the } \\
\text { slope }\end{array}$ \\
\cline { 2 - 3 } & $\begin{array}{l}\text { GMB strains along the } \\
\text { slope }\end{array}$ \\
\hline Fibre Optics & 15 & $\begin{array}{l}\text { GMB strains along the } \\
\text { slope }\end{array}$ \\
\hline Thermistors & 2 & GMB temperature \\
\hline $\begin{array}{l}\text { Additional } \\
\text { records }\end{array}$ & 7 & Waste height \\
\hline $\begin{array}{l}\text { Temperature } \\
\text { logger }\end{array}$ & 1 & GMB temperature \\
\hline
\end{tabular}

Table 2. Instruments and parameters measured at Milegate Extension Landfill.

\section{$4 \quad$ Measured parameters and methodology}

The proposed instrumentation at Milegate Extension Landfill provides the possibility of conducting a full-scale experiment with known dimensions, loadings and waste placement conditions. The experiment is designed to obtain information on relative displacements of lining elements, tensile behaviour of geosynthetic elements, loads applied to the lining system during and post waste placement, and temperature of lining components. Figure 5 presents schematically the location of instruments along the slope. It was considered of particular importance to monitor strains within the GMB with overlapping instruments to allow comparison and verification of the different approaches. 


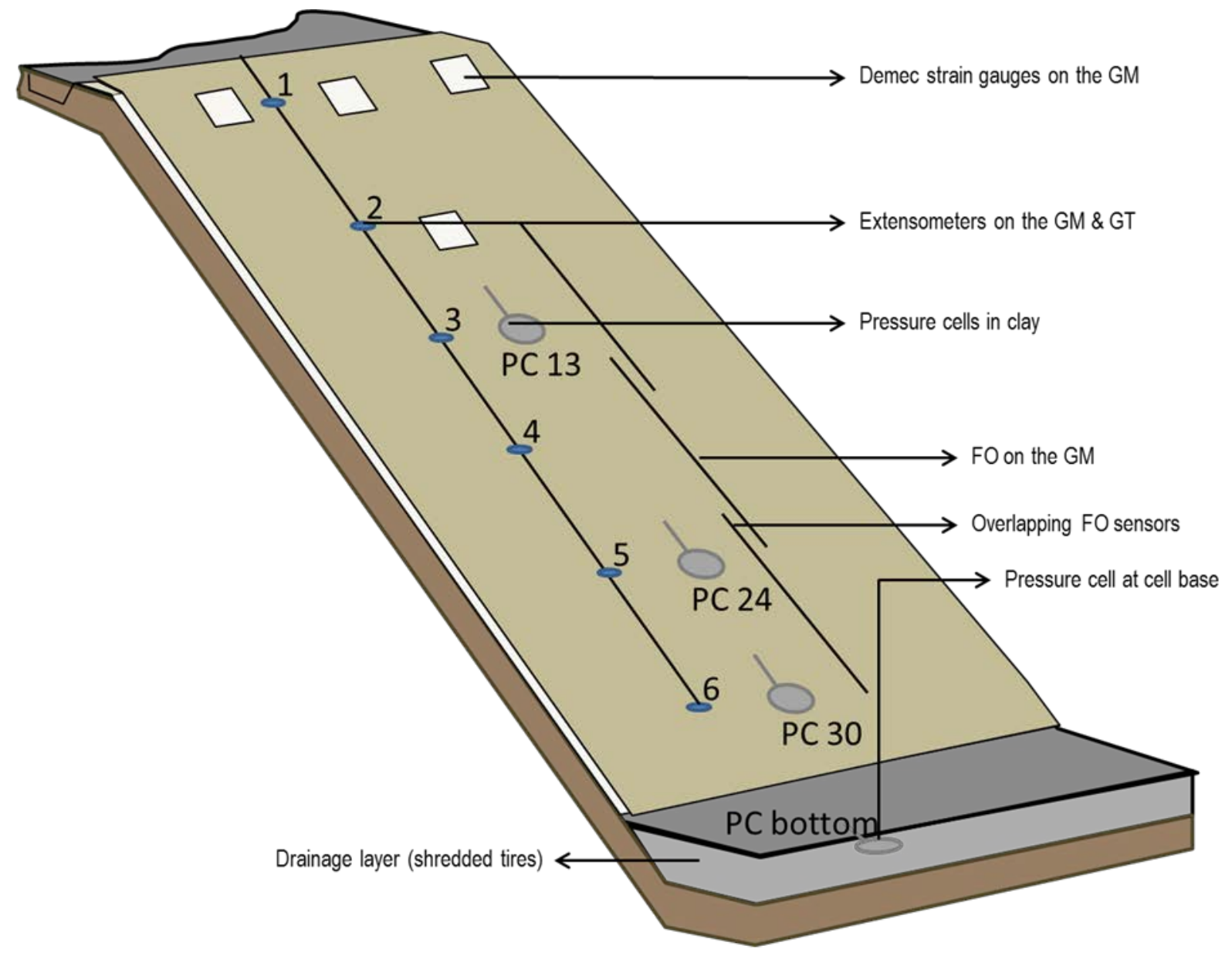

Figure 5. Schematic view of instrument locations along the slope.

\subsection{Pressures imposed on the liner - pressure cells}

Vibrating Wire Pressure Cells (PC) were chosen for installation in the top of the clay liner to measure total stresses imposed on the lining system during and after waste placement. They consist of two stainless steel plates welded together along their periphery. Space between the plates is filled with oil. Changes in the pressure on the plate surfaces corresponds to change of oil pressure within the cell, this is converted by a vibrating wire pressure transducer into an electrical signal, which is transmitted to the measuring table at the top of the slope where all cables terminate. Two of the PC are equipped with thermistors which allow the influence of temperature on measured pressure readings to be considered.

In total 4 vibrating wire PC were installed, 3 along the slope in shallow excavations and one in the cell base, placed in a plastic bag filled with sand under the one metre thick 
shredded tyre drainage layer. The cells were installed beneath the GMB, at distances $12.3 \mathrm{~m}$, $23.3 \mathrm{~m}$ and $29.3 \mathrm{~m}$ from the slope crest and one at the toe beneath the drainage layer. The second and third PC contained thermistors. Armoured cables attached to the instruments run along the GMB and GTX panel edge to the top of the slope, where readings are taken during site visits.

\subsection{Displacement and relative displacement of the geosynthetic layers}

Relatively simple wire extensometers (Dunnicliff 1993) were used as the method has already been proven to deliver valuable information about liner performance (e.g. Gourc et al. 1997). Six extensometers were installed on the GMB and six on the GTX. Each extensometer consisted of a wire (high tensile strength), with one end attached to the geosynthetics at locations along the slope measured from the crest of 3m, $8.4 \mathrm{~m}, 13.8 \mathrm{~m}, 19.2 \mathrm{~m}, 24.6 \mathrm{~m}$ and 30m. Figure 6 presents a schematic view of extensometer operation. The values of relative displacement between the geosynthetic lining elements are calculated from the GMB and GTX displacements. This follows the monitoring techniques used previously on landfill sites by Gourc et al. (1997), Koerner et al. (1997), Bouthot et al. (2003) and in laboratory research by Fowmes et al. (2008). This technique also allows calculation of strain values occurring within the GMB and GTX, though with relatively low accuracy and over a long gauge length. In terms of materials used to construct the extensometers it was essential to use durable high quality wire that can survive the robust landfill environment and ensure satisfactory performance during the years of monitoring. It is anticipated that the instruments would be exposed to elevated temperatures and mechanical impact due to waste placement and compaction. 


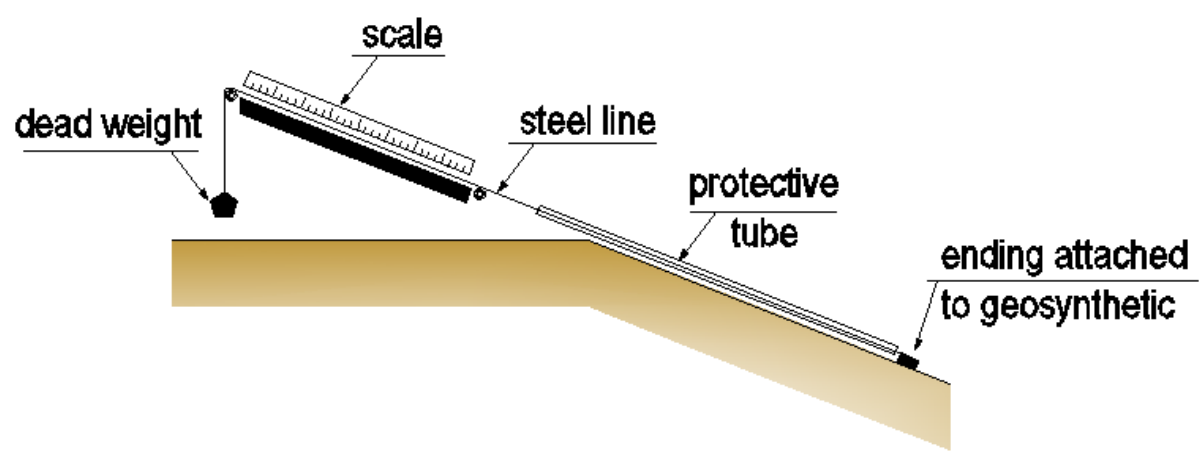

Figure 6. Extensometers operation.

Wire attachments to the GMB and GTX were prepared by drilling (GMB) or cutting (GTX) two holes measuring approximately $8 \mathrm{~mm}$ in diameter in the material allowing the wire to be pulled through and fastened in a loop. Holes in the GMB liner were acceptable in this case because it does not form part of the lining system required under the site hydrogeological risk assessment. The wires run up the slope in tubing to the measuring station. Free and smooth movement of the wire is ensured by the protective tubing which isolates the wire from forces imposed by the GMB, GTX and overburden (i.e. sand and waste). The wires pass through a system of pulleys across the measuring board (see Figure 7). Each wire is tensioned by an individual weight. To ensure sufficient durability of the instrument, wire rope $1.5 \mathrm{~mm}$ diameter made of AISI $31 \mathrm{G}$ steel was selected. The material and diameter of the protective tubing were determined by the ease of pulling wire through the tube in laboratory trials. Consequently $1.5 \mathrm{~mm}$ nylon tube was selected. Temperature influence on wire extension or contraction is estimated and a correction factor applied. 


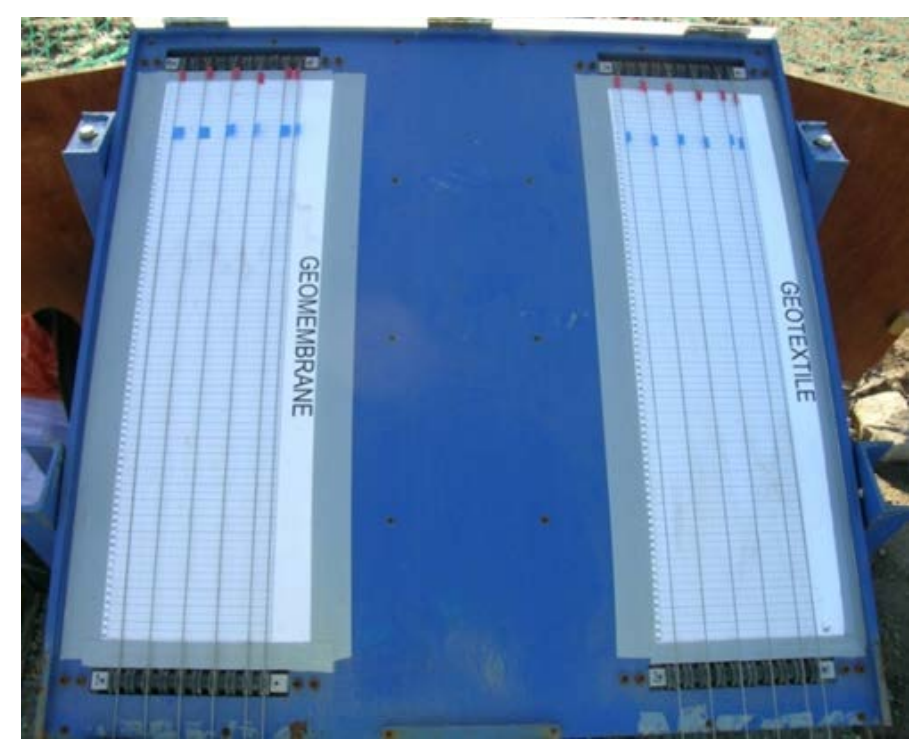

Figure 7. Extensometers measuring table

\subsection{Geomembrane strains and tensile behaviour}

Strains within the GMB are measured by three independent methods: Fibre Optic (FO) Bragg Gratings, Demec strain gauges and extensometers. Each of the methods measures average strains over a different gauge length (Table 3). GMB strain measurement allows calculation of tension forces developed within materials if the stress/strain behaviour is known. This is an important aspect of the research as generally it is a common practice when designing landfill lining systems to set failure criteria on allowable stress or strain values in the primary GMB liner (typically HDPE) so as to minimise the possibility of environmental stress cracking. This study provides information on in-service GMB strains in response to a range of known loadings conditions.

\begin{tabular}{|l|l|}
\hline Instrument & Gauge length \\
\hline Extensometers & $540 \mathrm{~cm}$ \\
\hline $\begin{array}{l}\text { Demec strain } \\
\text { gauges }\end{array}$ & $20 \mathrm{~cm}$ \\
\hline Fibre optics & $50 \mathrm{~cm}$ \\
\hline
\end{tabular}

Table 3. Distance of average strain measurement for different methods (i.e. gauge lengths). 


\subsubsection{Extensometers}

This method allows approximate calculation of average strains between any two adjacent anchor points on the geosynthetic (i.e. over a length of $5.4 \mathrm{~m}$ ). The measuring mechanism is robust with a relatively low resolution compared to the two other methods used on the site.

\subsubsection{Fibre optics}

FO were selected to measure both GMB strain and temperature. They are known to be relatively fragile but it was decided to deploy sensors along the GMB sheet in an attempt to obtain high resolution measurements. Figure 8 presents details of the FO measurement method. The system and method of deployment was developed by the Cranfield University Photonics Group. FO technology has been used in the study of geosynthetic for over 15 years. Geosynthetic sheets with embedded sensors are widely available but the technology is typically expensive. FO deformation monitoring systems have already been used to monitor geosynthetics including in landfill environments. Yashima et al. (2009) report strain distributions along a geogrid measured by FO installed in a longitudinal member of the geogrid. This was used to assess the stability of a geogrid reinforced soil wall during and after construction. Nakamura et al. (2006) report deformation within a landfill cap monitored using FO technology, and it is believed to have delivered information over a period of several years. Additionally various geotechnical applications of geosynthetic with embedded FO sensors were investigated and developed in France (i.e. Nancey et al. 2007, Loke et al. 2006, Artieres et al. 2010).

In this research, FO with Bragg Gratings were deployed on the GMB. Bragg Gratings are structures within the FO that reflect particular wavelengths (see Figure 8b). When light travels through the fibre core, a particular wavelength is reflected by the Bragg grating. Deformation induced within the GMB is characterised by the strain within fibre Bragg 
Grating causing a shift of wavelength, which is directly represented by the shifts in peaks of a spectrum graph (see Figure 8c).

FO installed at Milegate landfill were draw tower grating chains from FOS\&S (Fibre Optic Sensors \& Sensing Systems) with five strain sensors in each chain. The technology used by the company to write gratings in a fibre allows production of arrays without splicing. Six arrays of FO sensors were deployed at various positions along the slope. Three strings with 5 strain sensors each and 6 temperature sensors each were installed. Each array was originally $5 \mathrm{~m}$ long, but it was decided to extend each by adding additional FO strings in between the Bragg gratings to increase sensor coverage along the GMB sheet. In addition, the FO arrays were located on the slope to ensure that the last sensor on a string overlapped the first sensor of the next array (Figure 5). It was possible to cover approximately 25 meters of GMB slope length with FO strain sensors. Bragg Gratings produced by Cranfield University were also deployed on the GMB to measure temperature changes, as this strongly influences strain sensor measurements. 
a)

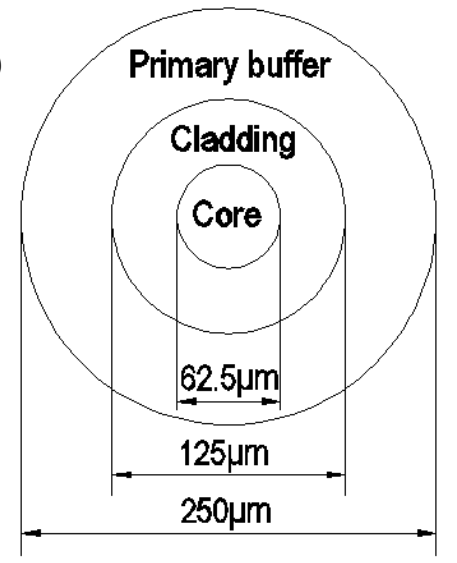

b)
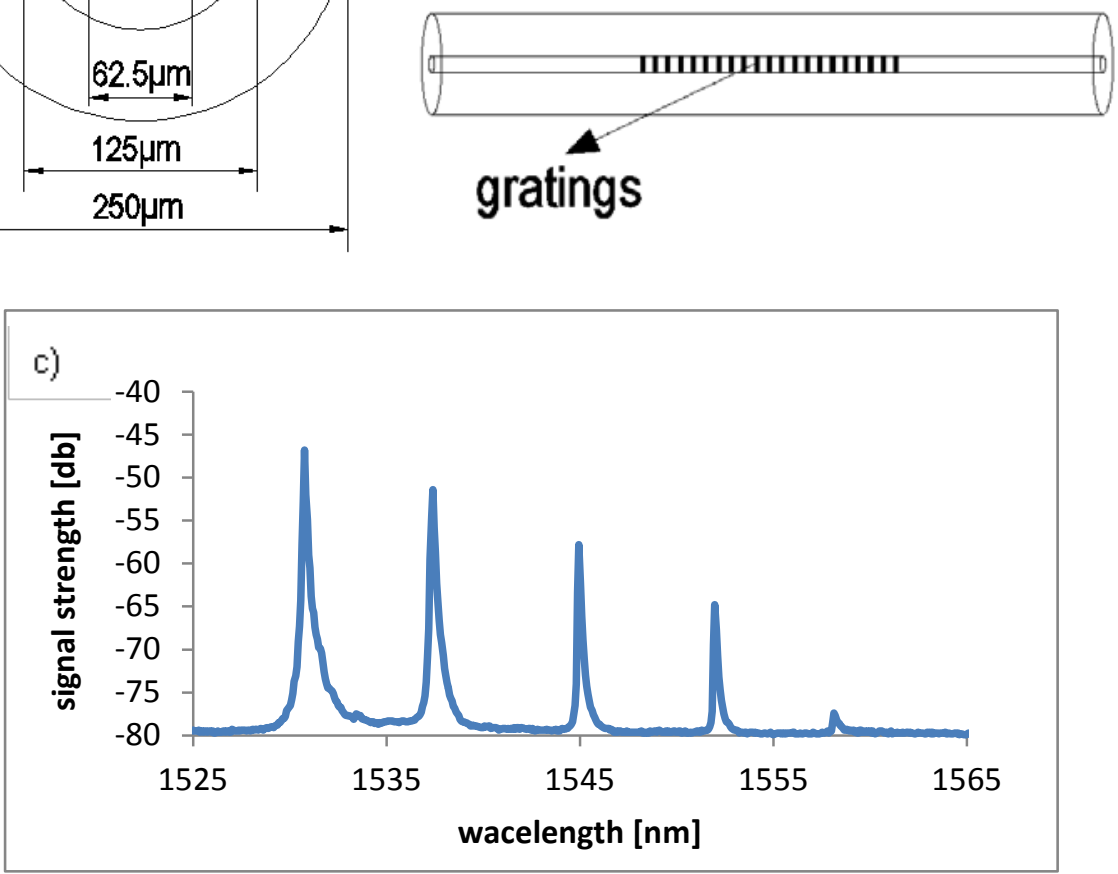

d)

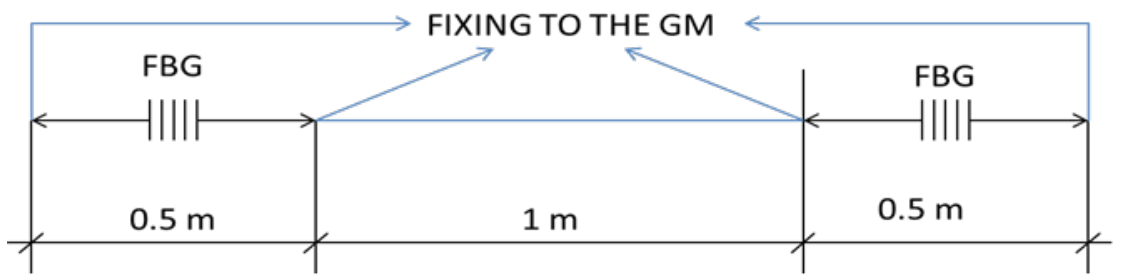

Figure 8. a) A typical size of the fibre (after Crisp and Elliot 2005); b) Uniform Fibre Bragg Grating (FBG); c) Typical wavelength spectrum; d) Schematic method of fibre Bragg grating installation on the GMB.

Strain gauges were located every second metre of the slope from the bottom. Fibre Bragg grating sensors are attached to the GMB to allow the strain to be measured over $0.5 \mathrm{~m}$ long gauge lengths (Figure 8d). To allow correct measurements of strains, the GMB surface had to be thoroughly polished to remove texture, dust and dirt and to obtain a smooth surface for FO sensor attachment. Both the GMB and FO coatings are low energy surfaces; therefore a structural plastic adhesive was used to adhere fibres to the GMB. In total, 15 strain and 7 
temperature FO sensors were installed along the GMB. Silicon sealant was used to cover and protect the whole length of each fibre string.

\subsubsection{Demec strain gauges}

Demec strain gauges were selected for deployment on the GMB because of the low cost, simplicity and robustness of the method. The change in distance between pairs of measurement points is used to measure strains using a standard measurement instrument. Demec gauges are widely applied in concrete science for strain measurement on concrete beams. This is typically accomplished in laboratory conditions and is used to define tensile forces occurring within concrete structures under load. To the Authors' knowledge the instrument has not previously been used in the landfill environment.

The reading instrument consists of an invar steel bar nominally $200 \mathrm{~mm}$ long with two conical-shaped points, one at each end, that are located in the receiving targets attached to the material. One of the conical points is able to rotate thus allowing the distance between them to vary. A dial gauge is used to measure the distance between the two measurement points to accuracy of $0.01 \mathrm{~mm}$. Stainless steel discs with a central depression to locate the conical point of the invar bar are attached to the GMB (Figure 9). Movement between the steel discs is obtained by a change in dial gauge reading. Measurements are taken manually during site visits. The purpose of these was to obtain tensile stresses near the anchorage point at the top of the slope by measuring strains and converting to stress. Four small U-shape incisions were made in the GTX to form flaps that gave access, with Demec steel discs located on the GMB beneath the flaps of GTX. Three measurement locations were installed along the crest of the slope and a fourth down the slope at the level of the first FO temperature sensor. Under each GTX flap four steel discs were glued to the GMB to form a square with approximately 200 mm side lengths. Use of pairs of discs in vertical and horizontal orientations allows strain readings down and across the slope respectively. 


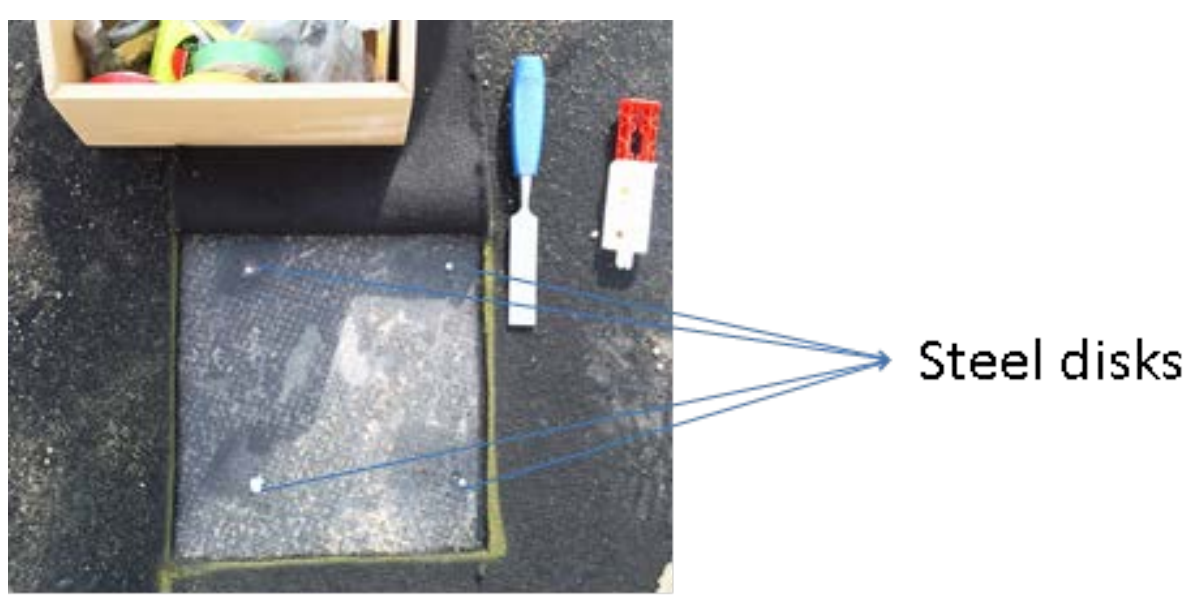

Figure 9. Demec strain gauges with steel disks placed approximately $200 \mathrm{~mm}$ apart in a square on the GMB.

The accuracy of Demec strain measurements in laboratory are at a micro scale $(0.001$ $\mathrm{mm}$ ), however the accuracy and precision of the GMB readings under site conditions is greatly reduced. Also, it was observed that the readout device can detect strains imposed on the GMB by the person obtaining the readings and hence care had to be taken to ensure that the person taking the readings did not influence the measurements. By taking this precaution the Demec strain gauges still provided consistent results (Section 7.2.2).

\subsection{Temperature of the Liner}

\subsubsection{Pressure Cell Thermistors}

Two of the four PC include an additional thermistor to measure temperature in the upper layer of the clay liner. The temperature is measured in the lower part of the slope: $24 \mathrm{~m}$ and 29.3 m below the slope crest. It was anticipated that the thermistors would allow application of temperature corrections for the PC readings but it was discovered that they were not suitable for the purpose (see Section 5).

\subsubsection{Fibre Optics}

Initially, temperatures were measured by FO in an attempt to provide temperature corrections for FO strain sensors, however limited reliability was achieved. 


\subsubsection{Temperature logger}

During the second year of monitoring a thermometer logger was installed on the site so the changes in temperature on the GMB surface could be recorded directly. The device was located underneath the GTX approximately 9m below the crest and temperature between the GMB and GTX liner was recorded every half hour. Temperature is an important driving force generating strains within the GMB in the early stage of the project (i.e. expansion during increasing temperature forming wrinkles that disappear during reducing temperature which caused contraction). This process has been observed even when the GMB is constrained under low overburden pressures. A key challenge is related to interpretation of temperature sensitive measurements when instruments are partially uncovered, i.e. covered by the sand veneer or partially covered by sand and waste (e.g. the extensometers), as the temperature varies along the length of the instrument.

\subsection{Waste height}

\subsubsection{Manual measurements}

Waste height above the slope toe is evaluated from ordinates which were marked at one metre increments along the slope after instrument installation. From this, waste height is estimated during each visit. When estimation of waste level is not clear, additional measurements with measuring tape are carried out. At the time of preparing this paper the waste level had increased relatively slow, reaching a height of $9 \mathrm{~m}$ measured from the cell toe.

\subsubsection{Laser scanning}

In order to collect detailed information about the slope, size of applied loadings (i.e. the veneer cover thickness), and waste body build up, 3D slope laser scanning (Figure 10) has been carried out. The slope was scanned on 28th September 2009 for the first time, when the length of uncovered slope was $29 \mathrm{~m}$. The resolution of the scanning is $1 \mathrm{~cm}$. The result of the scanning was compared with the design data of the slope, revealing good correlation (+/- 
$10 \mathrm{~cm}$ ) of the slope geometry. This was followed by scans conducted after the first veneer experiment in order to record full information about the veneer cover (Figure 11) and also before and after the second veneer trial. Figure 11 presents a profile showing a comparison of the original slope scanned data with the sand veneer upper surface. It is recognised that despite efforts taken to maintain an even thickness, the sand layer thickness varies between $\sim 0.4 \mathrm{~m}$ and $\sim 0.6 \mathrm{~m}$.

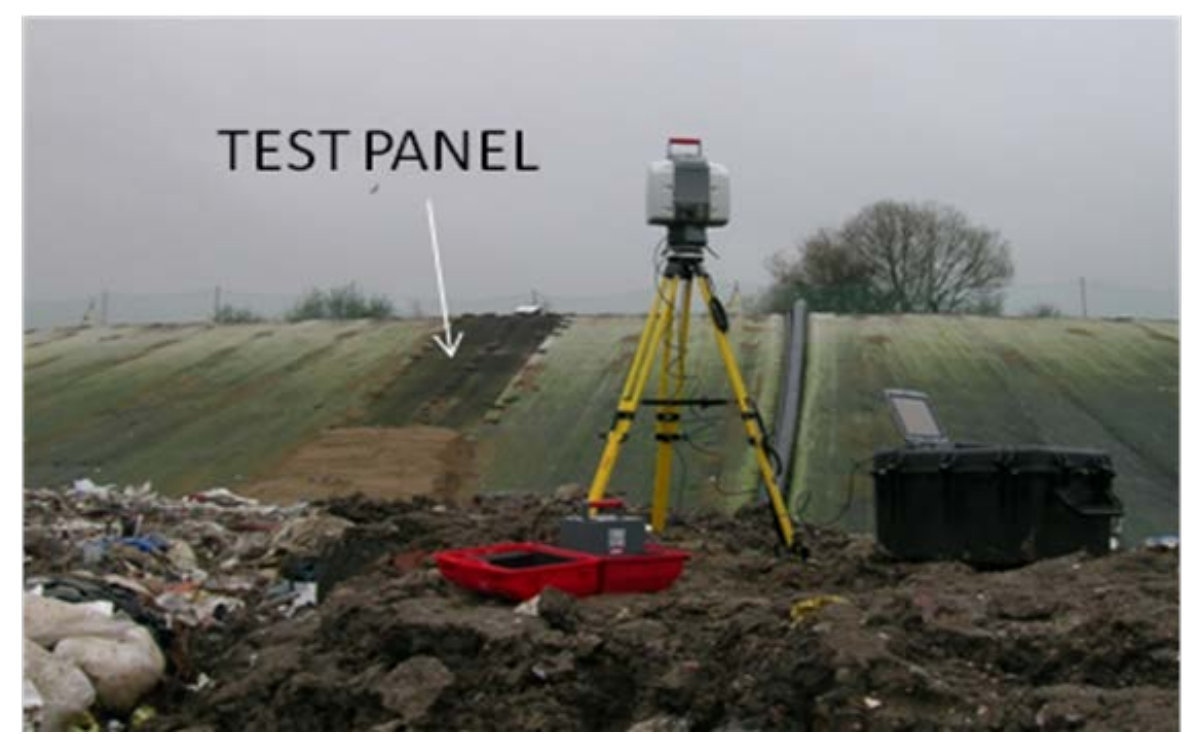

Figure 10. Laser scanning equipment positioned in front of the slope, after the first veneer experiment.

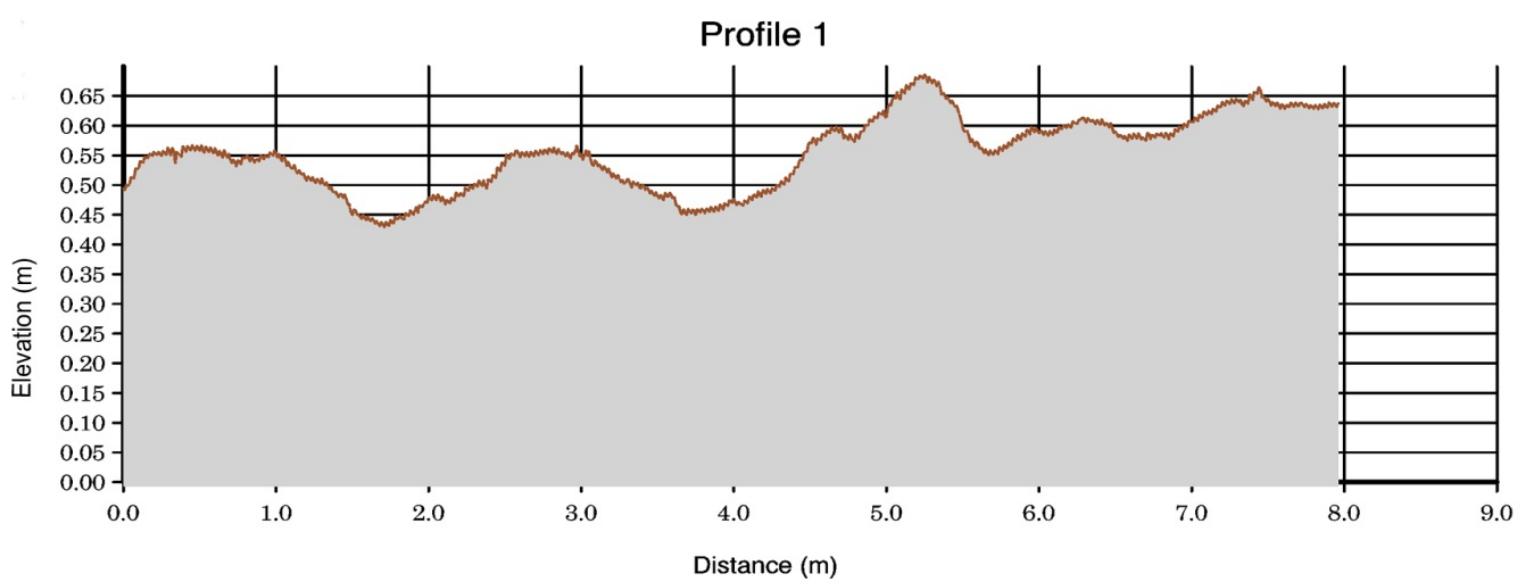

Figure 11. Sand cover profile for the 1st veneer calculated as the difference between laser scans conducted before and after veneer construction. 


\section{Instruments resolution and factors affecting measurements accuracy, precision and reading variability}

It is common for the terms accuracy, precision and resolution to be mixed up and misused. According to Dunncliff (1993) "accuracy is the closeness of approach of a measurement to the true value of the quantity measured. Accuracy is synonymous with degree of correctness. Accuracy of the instrument is evaluated during calibration", while "precision is the closeness of approach of each of a number of similar measurements to the arithmetic mean. Precision is synonymous with reproducibility and repeatability" and resolution is the smallest unit the measuring device is able to record. Table 4 presents parameters characterising measured values for particular instruments. In terms of strain measurement, as this was one of the most crucial parameters, using three independent methods of measurement adds confidence in the collected information.

Table 4 contains data regarding PC performance. Although the instrument resolution is reported by the manufacturer to be relatively high, it was observed that temperature readings are underestimated or not fully incorporated by the manufacturer within the corrected measurement. According to the instrument manual, correction was not supposed to be applied for PC with thermistors (i.e. they were self-calibrating), however after a period of time when the PC were exposed to atmospheric conditions, the readings clearly responded to seasonal temperature changes. Therefore additional analysis was undertaken in order to define a correction factor for temperature. Figure 12 presents temperature recorded by the PC located at the toe of the slope. 


\begin{tabular}{|l|l|l|l|l|}
\hline \multicolumn{1}{|c|}{ Instrument } & \multicolumn{1}{|c|}{ Accuracy } & \multicolumn{1}{|c|}{ Resolution } & \multicolumn{1}{|c|}{$\begin{array}{c}\text { Increment } \\
\text { size }\end{array}$} & $\begin{array}{l}\text { Instrument } \\
\text { range }\end{array}$ \\
\hline $\begin{array}{l}\text { Extensometers } \\
\text { Displacement }\end{array}$ & $+/-0.5 \mathrm{~mm}$ & $\begin{array}{l}0.5 \mathrm{~mm} \text { (for } \\
\text { displacement) }\end{array}$ & $1 \mathrm{~mm}$ & $1 \mathrm{~m}$ \\
\hline $\begin{array}{l}\text { Demec strain } \\
\text { gauges }\end{array}$ & $0.001 \mathrm{~mm}$ & $\begin{array}{l}4 \text { micro } \\
\text { strains }\end{array}$ & $1 \mathrm{~nm}$ & $\begin{array}{l}1 \% \text { long term } \\
5 \% \text { short } \\
\text { term }\end{array}$ \\
\hline Fibre optics & $\begin{array}{l}<=4 \mathrm{~nm} \\
\text { wavelength }\end{array}$ & & 0 to $1000 \mathrm{kPa}$ \\
\hline $\begin{array}{l}\text { Pressure cell no } \\
\text { thermistor }\end{array}$ & $\begin{array}{l}0.1 \% \text { of full } \\
\text { scale }=1 \mathrm{kPa}^{2}\end{array}$ & $\begin{array}{l}0.025 \% \text { of full } \\
\text { scale }=0.25 \mathrm{kPa}\end{array}$ & & 0 to $500 \mathrm{kPa}$ \\
\hline $\begin{array}{l}\text { Pressure cell } \\
\text { with thermistor }\end{array}$ & $\begin{array}{l}0.1 \% \text { of full } \\
\text { scale }=0.5 \mathrm{kPa}^{2}\end{array}$ & $\begin{array}{l}0.025 \% \text { of full } \\
\text { scale }=0.05 \mathrm{kPa}\end{array}$ & & \\
\hline
\end{tabular}

${ }^{1}$ According to Fibre Optic Sensing \& Sensing Systems - FOS\&S datasheet.

${ }^{2}$ Depends on a read out.

${ }^{3}$ Refers to the pressure transducer.

Table 4. Characterisation of instrument readings.

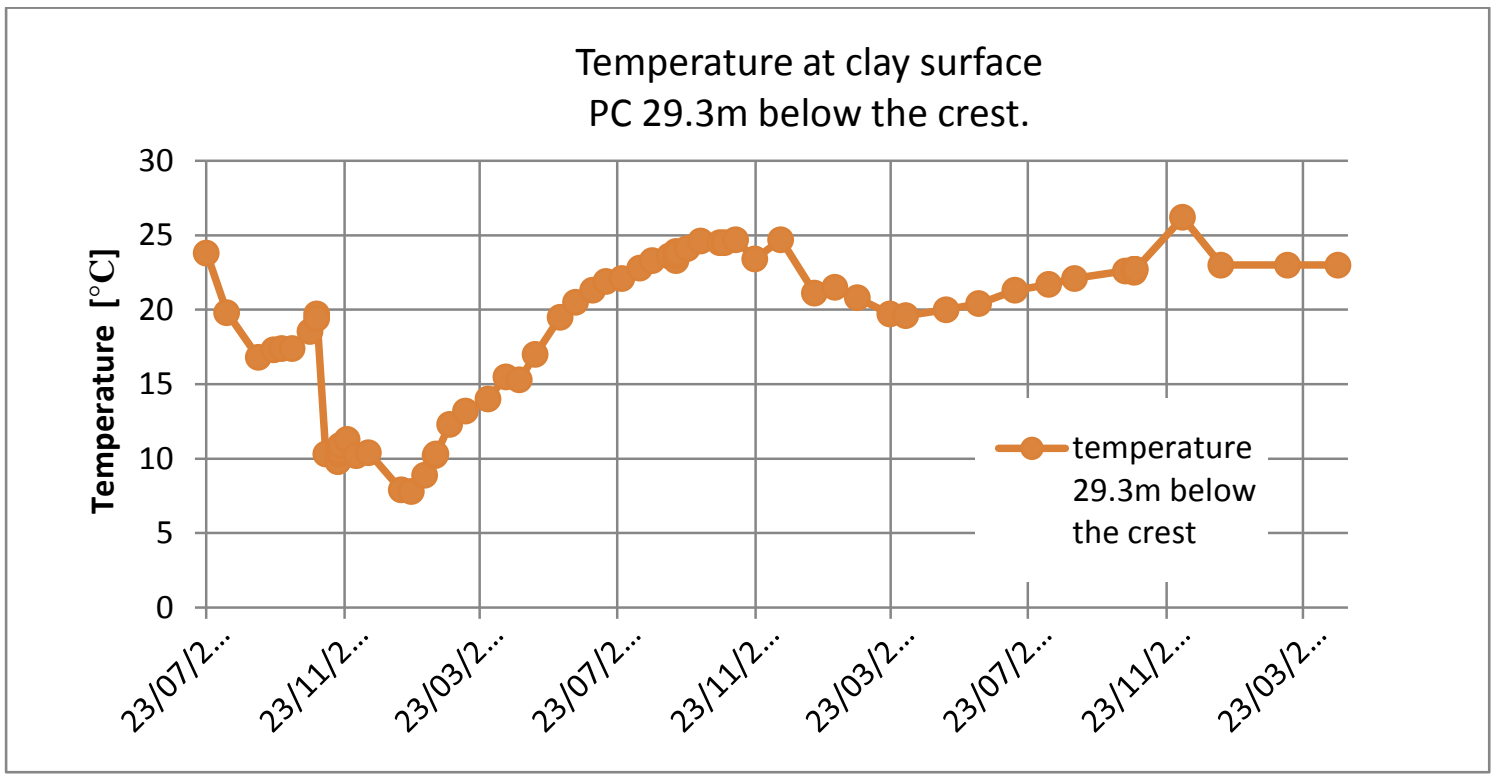

Figure 12. Temperature by the PC $29.3 \mathrm{~m}$ below the crest.

\section{$6 \quad$ Factors affecting readings and interpretation}

A well-equipped and performed full scale experiment potentially delivers a large amount of data and information. However it requires significant effort to obtain results and it is a complicated and challenging task to analyse and interpret the readings. Consideration has to be given to several aspects of instrument performance and the site environment. The following summarises factors taken into consideration while interpreting results: 
- Temperature and weather conditions - during the early stages of waste placement on the slope seasonal changes of temperature have more influence on material behaviour than loadings imposed on the materials. Although the readings from instruments are corrected for temperature changes, the GMB exhibits significant expansion/contraction in response to seasonal temperatures differences and also daily temperature changes;

- Veneer sand layer overburden pressure - controlled by variability of sand layer thickness and sand compaction density;

- Waste body overburden pressure - controlled by waste height, waste type and degree of waste compaction;

- Position of the instruments along the slope in relation to the loaded areas and response of instruments in relation to atmospheric factors;

- Possibility of erroneous readings due to operating error or faulty instrumentation;

- The cell stage of filling, the magnitude of imposed load from the waste compared with later stages of filling when the slope will be fully covered with waste and after site closure;

- FO strain and temperature sensors are very fragile, and although much attention was given to sensor installation to maximise durability, many of the sensors were damaged and became inoperable during the first year of the project. More robust protection could have been provided to the FO cables but a key aim was to minimise the instrument’s influence on the lining system performance.

\subsection{Instrument and material sensitivity to temperature changes}

Temperature was defined as a main factor strongly affecting all of the readings and therefore most of the data is processed to include temperature effects on instrument performance.

Table 5 presents values of temperature coefficients applied for particular instrument readings. 


\begin{tabular}{|l|l|}
\hline Instrument & Temperature sensitivity \\
\hline $\begin{array}{l}\text { Extensometers } \\
\text { (wire) }\end{array}$ & $16 \mu \mathrm{m} / \mathrm{m} /{ }^{\circ} \mathrm{C}$ \\
\hline Demec strain gauges & $\begin{array}{l}\text { (readings require HDPE } \\
\text { contraction/expansion analysis) }\end{array}$ \\
\hline Fibre optics & $0.01 \mathrm{~nm} /{ }^{\circ} \mathrm{C}$ \\
\hline Pressure cells & Calculated linear dependency \\
\hline
\end{tabular}

Table 5. Instruments temperature sensitivity.

\subsection{Extensometers temperature sensitivity}

Extensometer temperature dependence is relatively complicated to analyse, as the longest wires were partially covered by the sand layer and waste, partially by sand alone and partially just by GTX, therefore most of the time they were exposed to three different temperatures along their length. However, due to a lack of detailed spatial and temporal temperature information for these instruments the correction equation is based on the liner temperature obtained from the thermometer located under the GTX liner and which is not covered by the veneer sand layer. The coefficient of thermal expansion for steel used for the extensometer wires $\mathrm{C}_{\mathrm{t}}=16 \mu \mathrm{m} / \mathrm{m} /{ }^{\circ} \mathrm{C}$ (Koerner et.al. 1997 at Cinnciati landfill applied a factor $17 \mu \mathrm{m} / \mathrm{m} /{ }^{\circ} \mathrm{C}$ for the wire used). The longest wire rope on the slope is $32 \mathrm{~m}$ (30m along the slope $+2 \mathrm{~m}$ measuring table). In this case for a large temperature fluctuation, change in wire length can reach values of over $10 \mathrm{~mm}$. Table 6 shows the magnitude of contraction/expansion that can occur due to temperature change. The correction equation applied is as follows:

$$
C_{r}=R_{s}+L_{w} \times \Delta t \times C_{t} \text {, where }
$$

$\mathrm{C}_{\mathrm{r}} \quad$ - corrected reading;

$\mathrm{R}_{\mathrm{s}} \quad$ - original reading;

$\mathrm{L}_{\mathrm{w}} \quad$ - wire length;

$\Delta \mathrm{t} \quad$ - liner temperature difference (between first and current reading);

$C_{t} \quad$ - coefficient of thermal expansion for stainless steel AISI 316G; 
Note that when the temperature is below the initial commissioning reading, the correction value is subtracted; however when the current temperature is higher than the initial reading the temperature correction value is added.

\begin{tabular}{|c|c|c|c|c|c|}
\hline $\begin{array}{l}\text { point along } \\
\text { the slope }\end{array}$ & $\begin{array}{l}\text { wire length [m] } \\
\quad l=l_{0}+2 \mathrm{~m}\end{array}$ & $\begin{array}{c}\Delta \mathrm{l}[\mathrm{mm}] \\
\mathbf{f o r} \\
\Delta \mathrm{t}=\mathbf{1}^{\circ} \mathrm{C}\end{array}$ & $\begin{array}{c}\Delta \mathrm{l}[\mathrm{mm}] \\
\text { for } \\
\Delta \mathrm{t}=5^{\circ} \mathrm{C}\end{array}$ & $\begin{array}{c}\Delta \mathrm{l}[\mathrm{mm}] \\
\text { for } \\
\Delta \mathrm{t}=10^{\circ} \mathrm{C}\end{array}$ & $\begin{array}{c}\Delta \mathrm{l}[\mathrm{mm}] \\
\text { for } \\
\Delta \mathrm{t}=20^{\circ} \mathrm{C}\end{array}$ \\
\hline 1 & 5 & 0.08 & 0.4 & 0.8 & 1.6 \\
\hline 2 & 10.4 & 0.1664 & 0.832 & 1.664 & 3.328 \\
\hline 3 & 15.8 & 0.2528 & 1.264 & 2.528 & 5.056 \\
\hline 4 & 21.2 & 0.3392 & 1.696 & 3.392 & 6.784 \\
\hline 5 & 26.6 & 0.4256 & 2.128 & 4.256 & 8.512 \\
\hline 6 & 32 & 0.512 & 2.56 & 5.12 & 10.24 \\
\hline
\end{tabular}

Table 6. Extensometers wire response to temperature changes.

\section{$7 \quad$ Results from placement of second sand veneer}

Monitoring has been carried out at regular intervals since instrument installation, a period of 35 months, three sand veneers have been constructed and the cell is nearly full with waste. This monitoring to date includes evidence of significant influence of temperature on instrument and material performance. The more data that is available the easier it is to observe trends and identify inconsistent behaviour and errors. Therefore in order to establish long-term trends of behaviour significant effort has been given to achieve a full understanding of temperature influences, especially in cases where some of the instruments/materials are exposed to a daily temperature change, while others to only seasonal changes. This work is ongoing.

To demonstrate the type and quality of measured liner behaviour that has been achieved from the field trial, the results from the 2nd veneer sand placement experiment are presented. Only measurements made immediately before, during and on the day following the veneer construction are included. The short time period (two days) and the fact that there was no direct exposure to sun during this period (i.e. they were cloudy days), means that the temperature influence is minimal and can be neglected, as the measured temperature changes 
during the monitoring period were small. The location of the 2nd sand veneer is shown on Figure 4 and it was constructed in November 2010. During the one day construction period a $10 \mathrm{~m}$ sand layer, measured parallel to the slope, was placed in five $2 \mathrm{~m}$ long stages. The thickness of the sand veneer is approximately $0.5 \mathrm{~m}$. Instrument readings were taken, before construction started, after each $2 \mathrm{~m}$ fill stage and the day after.

\subsection{Displacements}

\subsubsection{Geotextile and geomembrane displacements}

Measurements from the robust extensometers reveal relatively large movements of both geosynthetic components. Loadings on the GTX are transferred to the GMB hence the displacement detected on the GTX are higher than on the GMB (Figures 13 and 14). Rectangles presented in the charts represent progression of the veneer placement stages, while sensor positions on the slope are schematically presented in the diagrams on a right hand side (Figures 13 - 19). First stage of the veneer placement caused up to $16 \mathrm{~mm}$ movement within the GTX. Initially the characteristic behaviour involves higher movements within the middle/lower parts of the slope (10-28mm on GTX and 4-18mm on the GMB), and lower within the upper parts of the slope $(0-6 \mathrm{~mm}$ on the GTX, $0-1 \mathrm{~mm}$ on the GMB). Moreover, some uphill movements are observed within the toe section of the GTX. It is suspected that excess of material might be folding at the slope bottom and this results in up slope displacements of the anchor point. The most significant downhill displacement within both materials is observed the day after construction. Within the middle part of the slope GTX displacements are in the range 8 to $28 \mathrm{~mm}$, while top and bottom are in the order of 9 to $16 \mathrm{~mm}$. The next day response of the GMB, have a smaller range with the middle section moving up to $18 \mathrm{~mm}$ while the crest section stays unchanged and the toe section displaces 4 to 8mm downhill. The lowest GMB extensometer does not change its location.

\subsubsection{Geotextile and geomembrane relative displacement}


Relative displacement occurring between the GMB and GTX is a calculated value obtained from recorded displacement of the two materials at the same slope position. This is presented in Figure 15. Positive values represent GTX movement exceeding GMB displacement down slope. Negative values indicate higher GMB movement. It is noticeable that the most significant slippage between materials occurs after the first $2 \mathrm{~m}$ stage of sand placement. In the middle part of the slope relative displacement reaches $20 \mathrm{~mm}$. The upper part of the slope follows the same trend but with values reaching $5 \mathrm{~mm}$, while toe section initially reaches values of 11 to $18 \mathrm{~mm}$ and is followed by decreasing relative displacement to end values of 5 to $8 \mathrm{~mm}$ of relative displacement. The measured relative displacements are of sufficient magnitude to mobilise post peak values of the GMB/GTX interface strength for the low normal stress conditions (e.g. Jones and Dixon 1998). It should be noted that these are incremental relative displacements in response to construction of the 2nd sand veneer and that the measured total relative displacements are larger.

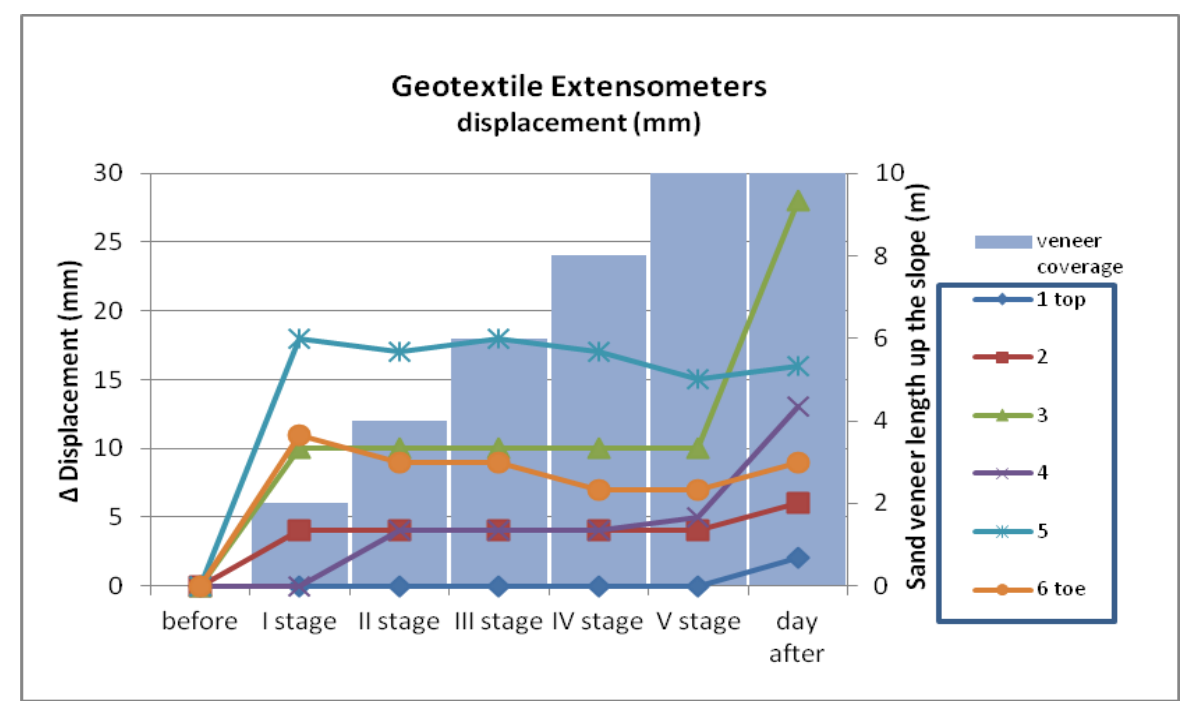

Figure 13. GTX extensometers readings before, during and after the 2 nd veneer trial. 


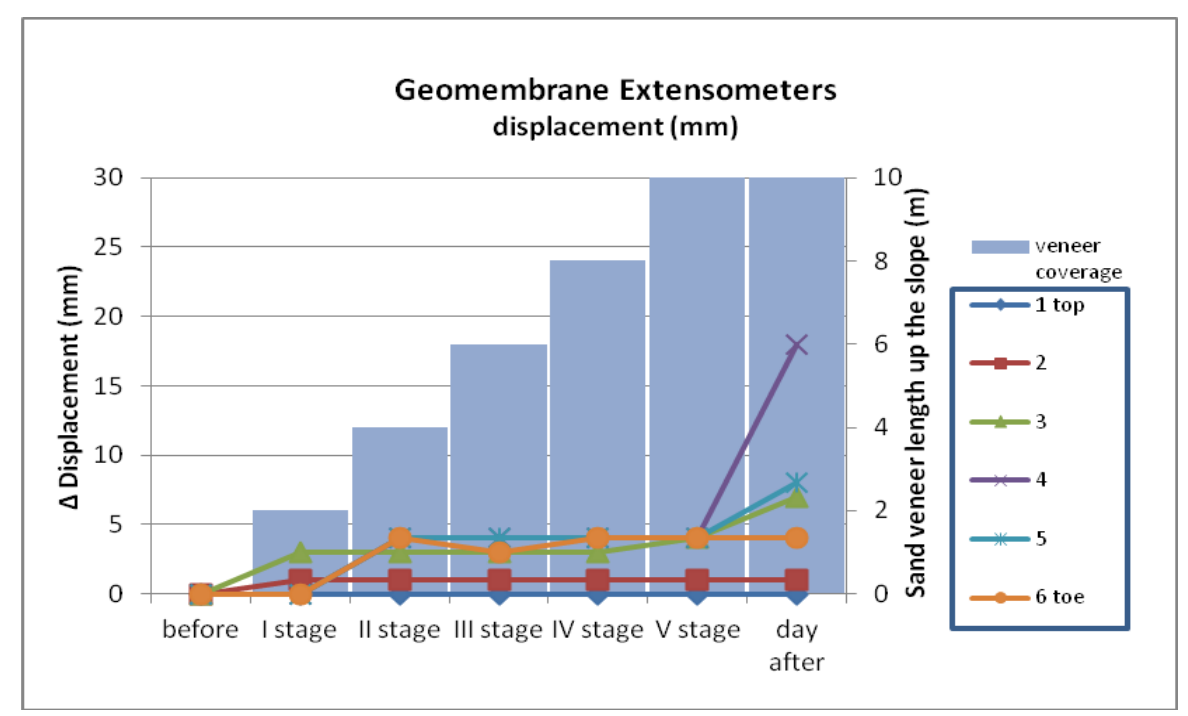

Figure 14. GMB extensometers displacement readings before, during and after the 2nd veneer trial.

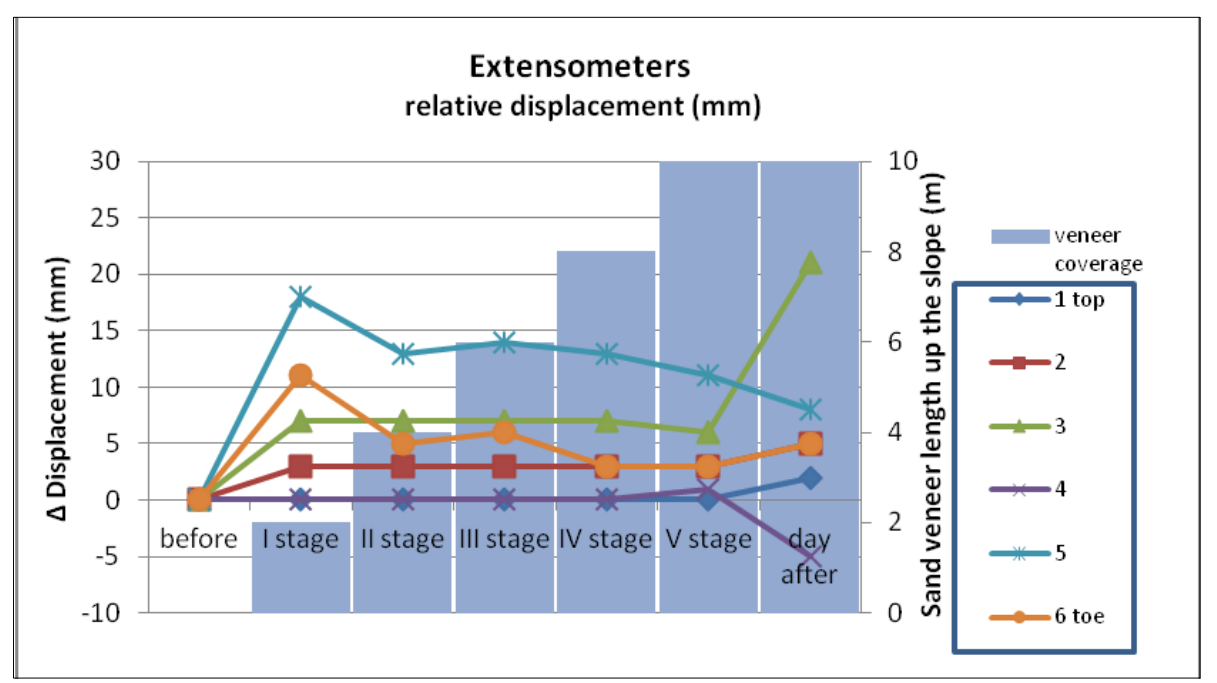

Figure 15. GMB/GTX relative displacement measured before, during and after the 2nd veneer trial.

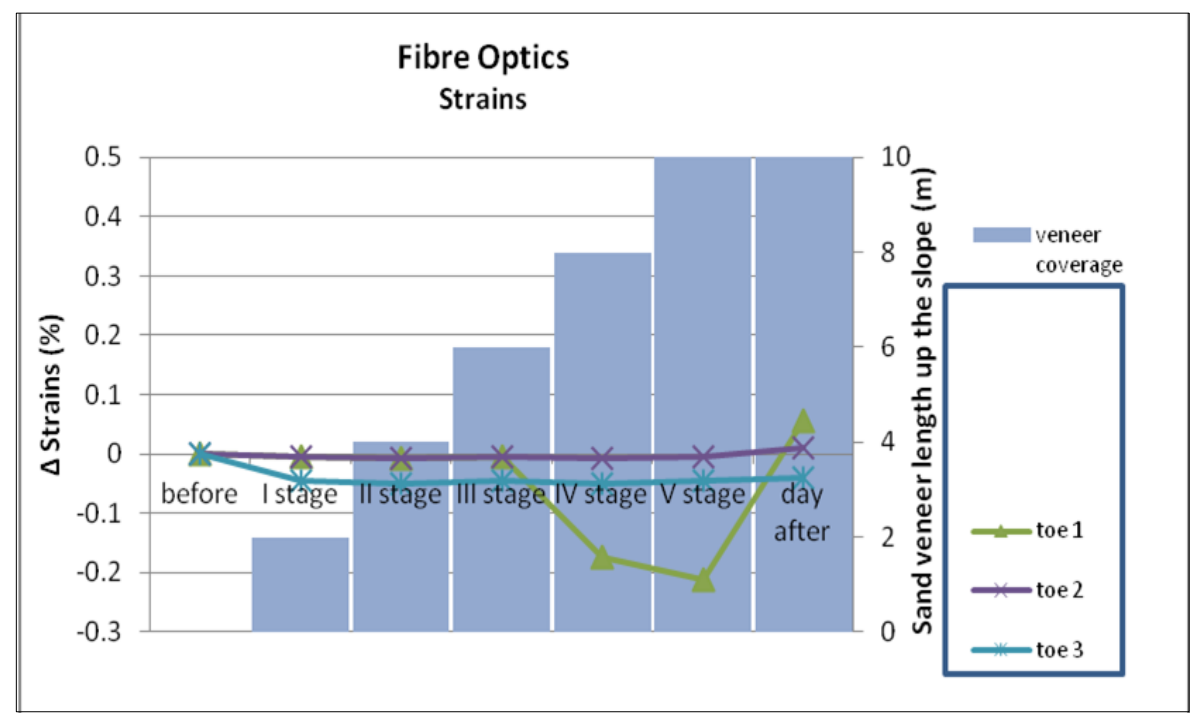

Figure 16. GMB FO strains readings before, during and after the 2nd veneer trial 


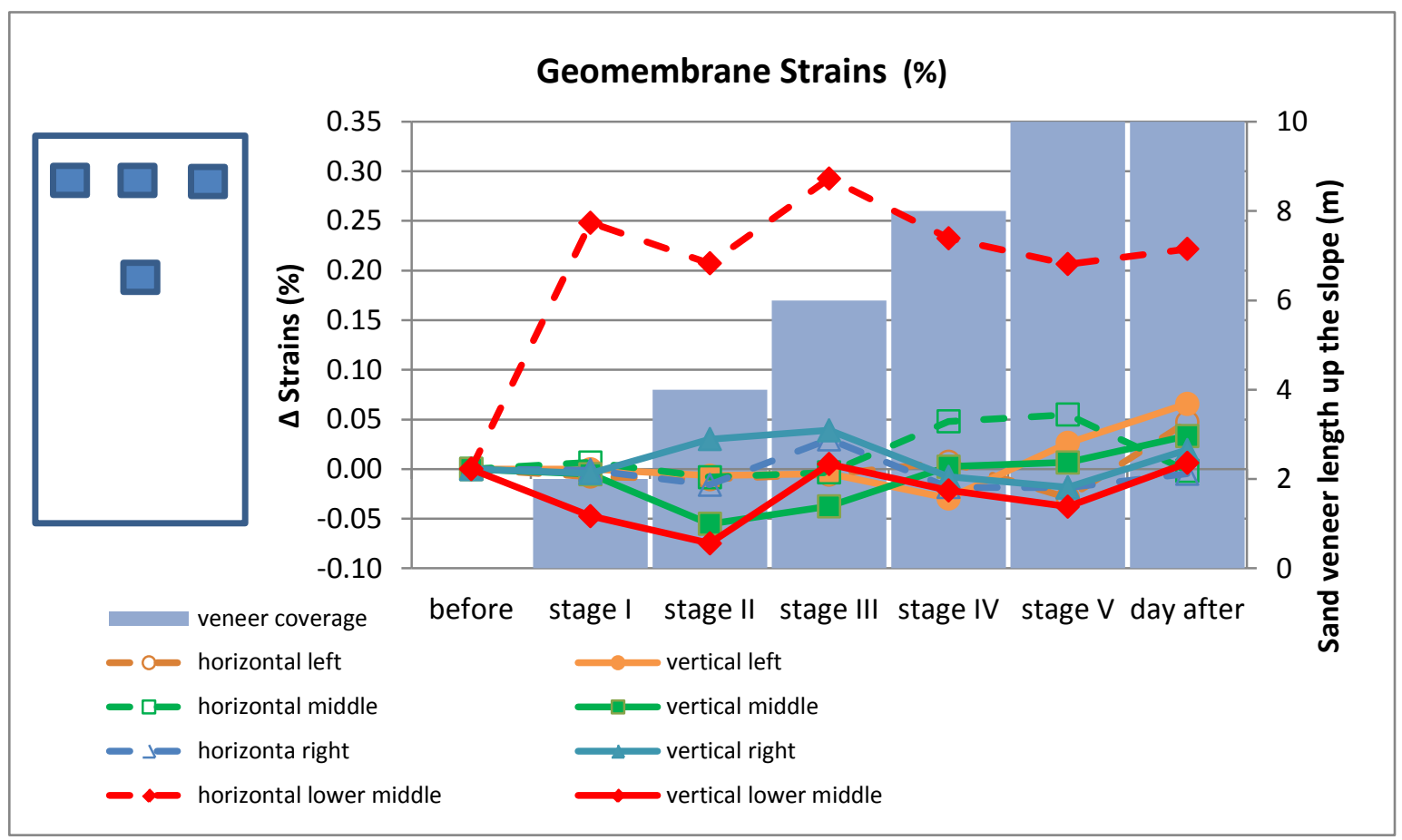

Figure 17. GMB strains - Demec strain gauges readings before, during and after the 2nd veneer trial.

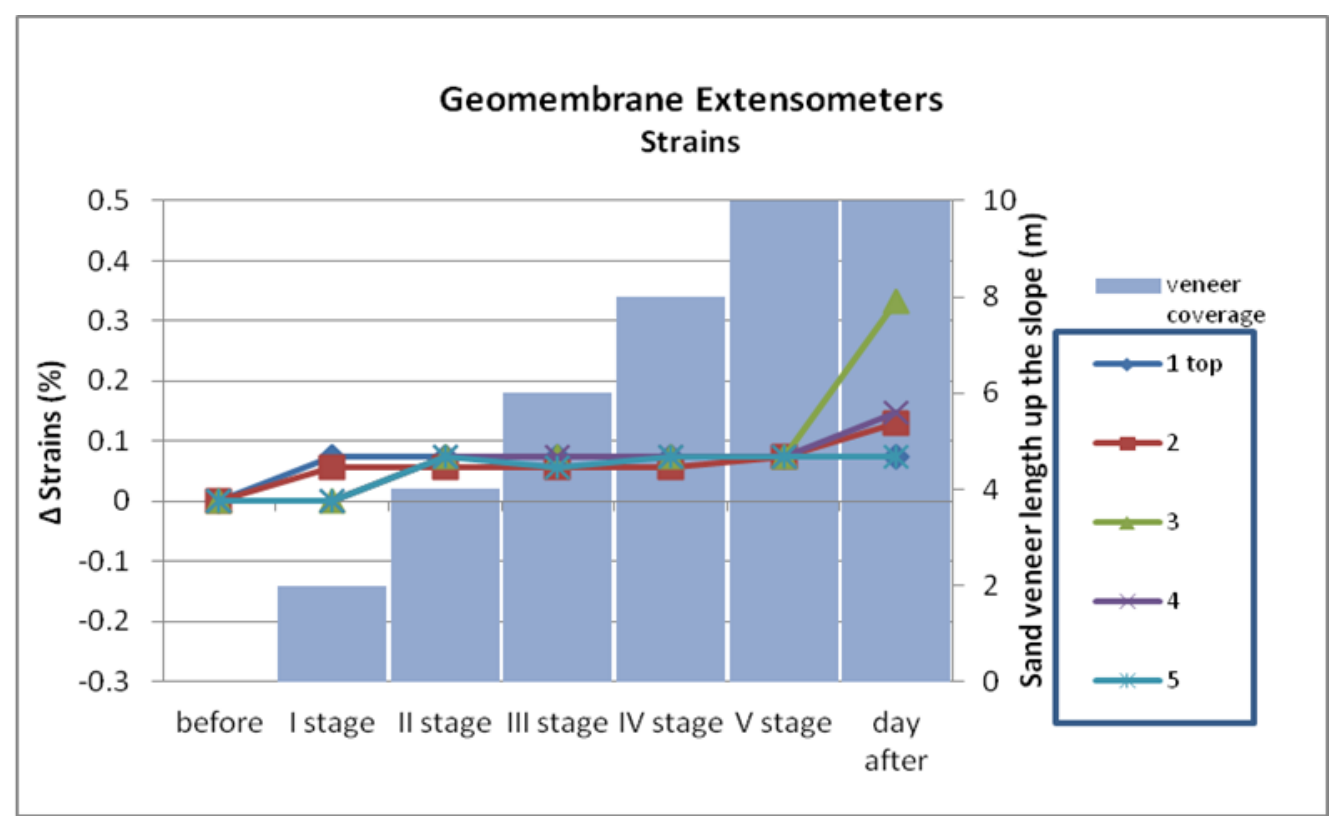

Figure 18. GMB strains calculated from extensometers displacements before, during and after the 2nd veneer trial. 


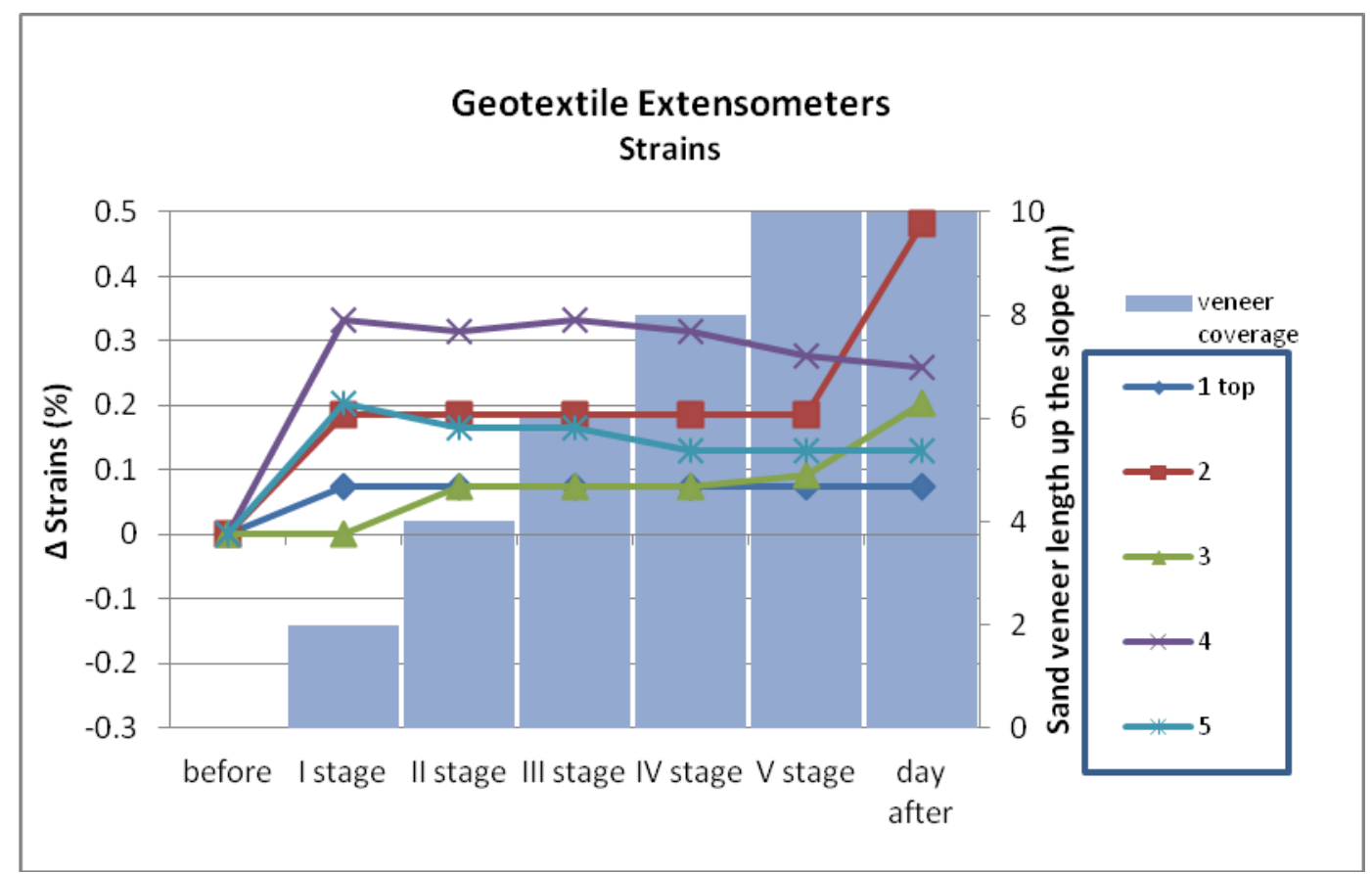

Figure 19. GTX strains calculated from extensometers displacements before, during and after the 2 nd veneer trial

\subsection{Strains}

\subsubsection{Fibre optics}

FO have the potential to provide very accurate strain measurements. Presented data (Figure 16) include readings recorded within the lower parts of the slope, for sensors installed close to the right hand side edge of the GMB. This part of the slope was already covered by the first sand veneer. In general, low contraction strains are detected near the toe. The 4th stage of veneer placement caused compression measurements for the GMB within the parts of the slope where extensometers detected uphill movements. While the two lower sensors stay within the same range, the top one ( $25 \mathrm{~m}$ below the crest) is subjected firstly to relatively high compressive strains $\sim 0.2 \%$, which changes by the next day to extension exceeding $0.25 \%$. The changes in measured strains the day after the veneer construction are considered to occur due to stress relaxation in the geosynthetic and are recorded by all instrumentation. 
Particular problems related to the FO strain measurement technology were:

- Periods with lack of response from sensors, although the same procedure was always followed when taking readings (e.g. maintaining clean connections and ensuring good attachment to reading device), periods of no readings were observed after which sensors responded again;

- Most of the sensors stopped responding after a year of monitoring. Although at first no particular reason was identified. It was thought that mechanical damage would be limited as the sensors had been protected under the sand layer for many weeks. However, site investigation revealed that the silicon sealant protection installed for the cables was insufficient and the sensors were broken.

\subsubsection{Demec strain gauges}

The four Demec strain gauges provide interesting data on strains within the GMB, because not only do they allow measurements of strains along the slope but also strains across the slope (Figure 17). Initially it was thought to use horizontal measurements to derive temperature corrections for strains along the GMB. However as the monitoring progressed it was observed that GMB strains across the slope are significant and even exceeding values of strains along the slope in some cases. However for the 2nd veneer experiment strains presented in Figure 17 are not subjected to major temperature changes as noted above. In general, strains for the three upper locations remain throughout the trial in the very low range of $+/-0.07 \%$, similar to the results obtained from FO. Interesting behaviour is observed within the middle section of the slope from the lower measurement position with an immediate high response of horizontal strains reaching $0.2 / 0.25 \%$. However, placement of the veneer has not resulted in any immediate response in terms of vertical GMB strains at this location, although by the next day tensile strains are again observed. The increases in tensile 
strains observed during the 2nd veneer placement are later compensated by material contraction when the temperature dropped during the winter period.

\subsubsection{Extensometers strain measurement}

An additional source of information on strains is provided by the extensometer measurements. Unlike the FO, extensometers are less delicate instruments, however also less precise and partially subjected to temperature changes as mentioned above, but they cover nearly all the length of the slope and measure strains within the GTX as well as GMB.

(1) Geomembrane strains

The GMB calculated strain values are in the range of values recorded by the FO and Demec strain gauges. Due to precision of the instrument, values are relatively constant and less oscillation within the plot is observed (Figure 18). It is encouraging that similar trends are observed, and recorded values are within the same range as for other strain measurement techniques.

(2) Geotextile strains

The GTX extensometers reveal larger tensile strains comparing to GMB (Figure 19). This is expected as GTX is directly subjected to imposed loadings from the sand veneer and the recorded displacements for GTX were mostly higher, and in addition the material has a lower tensile stiffness. The most noticeable response within the GTX is observed after the 1st stage of sand layer placement. Generally, strains along the GTX exhibit variable values from 0.07 to almost $0.5 \%$. Initially higher values are monitored within the lower sections of the slope, but on the next day the upper section of GTX had also stretched significantly, with an incremental strain of $0.3 \%$. 


\section{Further Work}

The main aim of the ongoing project is to validate numerical models used in landfill design approaches. Future work will comprise modelling the Milegate Landfill slope section in Fast Langrangian Analysis of Continua (FLAC) software, which is a finite difference numerical modelling software and can be used to model multiple strain softening interfaces between components (Fowmes et al. 2008) and staged construction. Computed results will be compared with the in situ measured behaviour and the design approach evaluated.

To support this stage of the investigation large direct shear box tests have been conducted on multiple samples of materials from Milegate Landfill to establish the interface shear strength properties between the lining system components, including statistical characterisation and input data for the numerical modelling validation. It is planned to continue monitoring until waste placement is complete and, if possible, for an extended period after closure of the landfill. As data becomes available it will be possible to continue interpretation of information from the site and to more clearly define factors influencing behaviour.

\section{Conclusions}

In the last 20 years much progress has been made in understanding geosynthetic behaviour within landfill lining systems and mechanisms of composite liner performance. In recent years significant attention has been given to developing appropriate modelling of the landfill lining system including characteristic behaviour of materials, stages of construction and advanced waste models, in order to demonstrate acceptable design.

Design process is usually a complicated and time consuming procedure, often supported by many simplifications and assumptions. When numerical modelling software is applied within the design process, it is important to acquire confidence in the computed results. Therefore, 
full scale experiments are of crucial importance to establish confidence in design, ensure safety and to allow future design development. The experiment being carried out at Milegate Extension Landfill has provided an opportunity to conduct a full-scale trial with known dimensions, loadings and waste placement conditions. This gives an opportunity to obtain valuable information to aid the design of future landfill lining systems and to assess performance of existing systems. This study aims to obtain information on relative displacements of lining elements, tensile behaviour of geosynthetic elements, loads applied to the liner system and on temperature influences on GMB behaviour during construction stages and after landfill closure.

Data delivered from the three strain measurement instruments gives an opportunity to compare results from independent methods: Demec strain gauges, FO and extensometers. It has to be emphasised that cell filling has progressed slowly, currently the cell is nearly full. Consequently measured pressures imposed on the GMB within lower parts of the slope only reach values of $50 \mathrm{kPa}$. However this has provided an opportunity to establish instrument behaviour and temperature influences on their performance. Many challenges associated with site experiment and data processing have been addressed, including a lack of information about instruments response to temperature changes. As the trial continues, more data that is available that makes it easier to identify and to understand temperature controlled material behaviour and instrumentation response. Considerable effort has been focused on establishing consistent readings and rigorous interpretation criteria.

To date all strain gauge types have provided useful results. Although a few responses are incoherent, readings from all three sources show the same trends and ranges. This provides confidence in collected readings. An important finding is that in the early stages of the cell 
filling, the most significant influence on behaviour of the lining system comes from temperature changes (i.e. greater than from loading). Significant strains and displacements of the GTX and GMB lining elements have occurred in response to construction of the sand veneers and placement of waste. This loading has also generated relative displacements between the GTX and GMB that are of sufficient magnitude to generate post peak interface shear strengths. This has important implications for the selection of parameters for use in limit equilibrium analyses of waste mass stability against the slope both during construction and in the long term. Measured horizontal strains across the slope provide information on GMB response to both changes in temperature and loading from the soil veneer and waste. It is believed that confidence can be attributed to the results obtained from the Milegate Extension Landfill trial due to the effort paid to instrumentation selection, performance and comparison between methods of measurements.

\section{ACKNOLEDGEMENTS}

The Authors wish to thank Milegate Extension Landfill Management for their support, which has made the project possible. Special thanks are due to Scott Hodges from Sandsfield Gravel Ltd for technical support. The authors also wish to thank GeoFabrics Ltd and VEOLIA Environmental Services Ltd for providing GTX and GMB materials respectively and to the Environment Agency England and Wales for their support of the trial. EPSRC, CICE at Loughborough University and Golder Associates UK Ltd are funding Engineering Doctorate student Katarzyna Zamara. Finally thanks are due to Dr Steve James and his researchers at Cranfield University for developing and installing the fibre optic strain measurement system and Rene Wackrow for his time and involvement in the slope surveying. 


\section{References}

Artieres, O., Beck, Y.L., Fry, J.J., Guidoux, C., Pinettes, P., 2010. Monitoring of earthdams leaks and stability with fibre-optics based monitoring system. 8th ICOLD European Symposium.

Bouthot, M., Blond, E., Fortin, A., Vermeersch, O.G., Quesnel, P., Davidson, S., 2003. Landfill extension using geogrids as reinforcement. Discussion and case study in Quebec http://www.infogeos.com/view.php?ID=569

Byrne, R.J., Kendall, J., Brown, S., 1992. Cause and mechanism of failure of Kettlemans Hills Landfill. In: Proceedings of ASCE Conference on Stability and Performance of Slopes and Embankment II, pp. 1-23.

Chang, M.-H., Mitchell, J.K., Seed, Raymond, B., 1999. Model Studies of the 1989 Kettleman Hills Landfil Failure. Geotechnical Testing Journal, Volume: 22, Issue Number: 1.

Council of the European Union (1999). Directive. 1999/31/EC on the landfilling of waste. Official Journal of the European Union, L 182, 1-19.

Crisp,J., Elliot B.J., 2005. Introduction to fiber optics. 3'rd edition, Newnes.

Dixon, N., Jones, D. R., 2003. Stability of Landfill Lining Systems: Report no.2 Guidance. Environment Agency Research and Development Technical Report P1-385/TR2.

Dixon, N., Jones, D. R., 2005. Engineering properties of municipal solid waste. Geotextiles and Geomembranes 23, pp. 205-233.

Dunnicliff, J., 1993. Geotechnical Instrumentation for Monitoring Field Performance, Whiley-Interscience, New York.

Environment Agency (England and Wales) (2002). Landfill regulatory guidance note 6. Interpretation of the engineering requirements of schedule 2 of the Landfill (England and Wales) Regulations 2002. 
Fassett, J.B., Leonardo, G.A., Repetto, P.C., 1994. Geotechnical properties of municipal solid waste and their use in landfill design. Waste Tech’94, Landfill Technology Technical Proceedings, Charlesto, SC (USA), January 13-14.

Fowmes, G.J., Dixon, N., Jones, D.R.V., 2008. Validation of a numerical modelling technique for multilayered geosynthetic landfill lining systems. Geotextiles and Geomembranes 26, pp. 109-121.

Gotteland, P., Gourc, J.P., Alboura, A., Thomas, S., 2002. On site determination of geomechanical characteristic of waste. Proceedings GeoEng 2000, The Institute of Engineers, Australia.

Gourc, J.P., Berroir G., Stock R., Begassa P., 1997. Assessment of lining systems behaviour on slopes, Proceedings of Sardinia 1997, Sixth International Landfill Symposium , Cagliari, Italy.

Gourc, J.P., Camp, S., Viswanadham, B.V.S., Rajesh, S., 2010. Deformation behaviour of clay cap barriers of hazardous waste containment systems: Full-scale and centrifuge test. Geotextiles and Geomembranes Volume 28, Issue 3, pp. 281-291 IS Kyushu 2007 Special Issue on New Horizons in Earth Reinforcement, 5th International Symposium on Earth Reinforcement.

Jones, D.R.V., Dixon, N. (1998). Shear strength parameters of geomembrane/geotextile interfaces. Geotextiles and Geomembranes vol.16, pp. 45-71.

Kodikara, J., 2000. Analysis of tension development in geomembranes placed on landfill slopes. Geotextiles and Geomembranes vol.18, pp. 47-61.

Koerner, R.M., Bowders, J.J., Scranton, H.B., 1997, Instrumentation for Monitoring Field Performance of the Cincinnati GCL Test Plots Geotextiles and Geomembranes vol.15, pp. 341-365. 
Koerner, R.M., Soong, T-Y. 2000. Stability Assessment of 10 Large Landfill Failures Geodenver 2000 ASCE SPECIA vol 103, pp. 1-38.

Loke, K.H., Kongkitkul, W., Tatsuoka, F. 2006. Fibre optic technology in geosynthetic instrumentation for monitoring of soil structures. Proceedings of 8th International Conference on Geosynthetics, Yokohama, Japan 2006.

Machado, S.L., Carvalho, M.F., and Vilaro, M., 2002. Constitutive model for municipal solid waste. Journal of Geotechnical and Geoenvironmental Engineering, 129. (4), pp. 372-378.

Mitchell, J.K., Seed, R.B. and Seed, H.B., 1990. Kettleman Hills Waste Landfill Slope Failure I: Liner-system properties, Journal of Geotechnical Engineering, ASCE 116 (4), pp. 647-668.

Muhsiung, C., 2005. Three-dimensional stability analysis of the Kettleman Hills landfill slope failure based on observed sliding-block mechanism. Computers and Geotechnics 32, pp. 587-599.

Najser, J., Masin, D., Bohac, J., 2010. Numerical modelling of lumpy clay landfill. International Journal for Numerical and Analytical Methods in Geomechanics. Published online in Wiley Online Library (wileyonlinelibrary.com). DOI: 10.1002/nag.990

Nakamura, J., Sakanishi, M., Kitazawa, A., Kumagai, K., Fujihashi, K., Ogasawara, T., 2006. Deformation measurement technology of geomembrane at controlled landfills using optical fiber sensors. Geosynthetics, Volumes 1-4. Proceedings of the 8th International Conference on Geosynthetics (8ICG), Yokohama, Japan, 18-22 September, 2006, pp. 203-206. 
Nancey, A., Lacina, B., Henderson, J., 2007. Geotextile and optc fibres: feedback after four years of use in soil. Geosynthetics 2007 GRI-20 proceedings, January 16-17, Washington D.C.

Rowe, R.K., Hoor, A. 2009. Predicted temperatures and service lives of secondary geomembrane landfill liners. Geosynthetics International, 16, No. 2, pp. 71-82.

Rowe, R.K., Islam, M.Z., Hsuan, Y.G., 2008. Leachate chemical composition effects on OIT depletion in an HDPE geomembrane. Geosynthetics International, 15 No. 2, pp. 136-151.

Rowe, R.K., Sangam, H.P., 2002. Effects of exposure conditions on the depletion of antioxidants from high-density polyethylene (HDPE) geomembranes. Canadian Geotechnical Journal 39, pp. 1221-1230.

Seed, R.B., Mitchell, J.K., Seed H.B., 1990. Kettleman Hills Waste Landfill Slope Failure. II: Stability analysis, Journal of Geotechnical Engineering, ASCE 116 (4), pp. 669691.

Sia, A.H.I., 2007. Landfill Lining Engineering Designs: A probabilistic approach. Unpublished PhD thesis, Loughborough University. November 2007.

Stoltz, G, Gourc, J.P., Oxarango, L, 2010. Characterisation of the physico-mechanical parameters of MSW. Waste Management 30 (2010), pp. 1439-1449.

Thusyanthan, N.I., Madabhushi, S.P.G., Singh, S., 2007. Tension in geomembranes on landfill slopes under static and earthquake loading — Centrifuge study. Geotextiles and Geomembranes Volume 25, Issue 2, April 2007, pp. 78-95 Special Issue on Geosynthetics in Harsh Environments

Villard, P., Gourc, J.P., Feki, N., 1999. Analysis of geosynthetic lining system (GLS) undergoing large deformations. Geotextiles and Geomembranes, Volume 17, Issue 1 February 1999, pp. 17-32. 
Viswanadham B.V.S., Rajesh S., 2009. Centrifuge model tests on clay based engineered barriers subjected to differential settlements. Applied Clay Science Volume 42, Issues 3-4, January, pp. 460-472.

Yashima, A., Tsuji, S., Yoshida, K., Yokota, Y., 2009. A new optical fibre sensor to assess the stability of geogrid-reinforced soil walls. Geosynthetics International, 16, No.4, pp. 2238-245.

Zhang, B., 2007. Constitutive modelling of municipal solid waste. Ph.D. thesis, Civil and Building Engineering, Loughborough University, United Kingdom. 